\title{
SOBRE LA TITULARIDAD DEL DERECHO DE AUTOR DE LA OBRA CREADA EN CUMPLIMIENTO DE FUNCIONES \\ LABORALES Y LA VALIDEZ, LÍMITES Y ALCANCES DE LA CESIÓN ANTICIPADA
}

\begin{abstract}
About the ownership of the copyright of the work created in fulfillment of labor functions, and the validity, limits and scope of the cession of rights anticipated in favor of the employer
\end{abstract}

Sebastián Campos Micin*

UNIVERSIDAD DE CHILE

SANTIAGO, CHILE

\footnotetext{
* Abogado. Licenciado en Ciencias Jurídicas y Sociales, Universidad de Chile. Diplomado en Nuevas Tendencias en Contratos y Daños, Pontificia Universidad Católica de Chile. Diplomado en Problemas Actuales del Derecho Contractual del Consumo, Universidad de Chile. Alumno regular del programa de Magíster en Derecho con mención en Derecho Privado, Universidad de Chile. Profesor de Derecho Civil, Universidad Central y Universidad de Las Américas. Correo electrónico:<sebastian@abuslemepinto.cl $>$.
}

Artículo recibido el 12 de febrero de 2018 y aceptado para publicación el 23 de abril de 2018. 
RESUMEN: El presente artículo trata sobre la titularidad del Derecho de autor de la obra creada en cumplimiento de funciones laborales, y la validez, límites y alcances de la cesión anticipada en favor del empleador. El análisis se desarrolla a partir de la constatación previa de la concepción del Derecho de autor que parece recoger nuestro ordenamiento jurídico. La titularidad se presenta como un problema de colisión de principios, con distintas soluciones en Derecho comparado, y resuelto en nuestro ordenamiento jurídico por los artículos 7 de la Ley de Propiedad Intelectual y $19 n^{\circ} 25$ de la Constitución Política de la República, que concretan la regla general. A su vez, la validez, límites y alcances de la cesión se examinan sobre la base de la libre transferibilidad de las prerrogativas patrimoniales que integran el Derecho de autor, revisando las exigencias, formalidades y limitaciones que pueden desprenderse del Código del Trabajo y de la propia Ley de Propiedad Intelectual.

PALABRAS CLAVE: Derecho de autor, titularidad, contrato de trabajo, cesión anticipada.

ABSTRACT: This article deals with the ownership of the copyright of the work created in full filment of labor functions, and the validity, limits and scope of the anticipated cession of rights in favor of the employer. The analysis is developed from the previous verification of the conception of copyright that seems to gather our legal system. Ownership is presented as a problem of collision of principles, with different solutions in comparative law, and resolved in our legal system by articles 7 of the Intellectual Property Law and 19 No. 25 of the Constitution, which specify the general rule. At the same time, the validity, limits and scope of the cession are examined on the basis of the free transfer of the patrimonial prerogatives that integrate the copyright, reviewing the requirements, formalities and limitations that can be understood of the Labor Code and the Intellectual Property Law itself.

KEYWORDS: Copyright, ownership, contract of employment, anticipated cession of rights. 


\section{INTRODUCCIÓN}

La coherencia e integridad del ordenamiento jurídico, si acaso se cree en tales ideales, encuentran auxilio en ciertos estándares normativos e indeterminados que la doctrina tiende a denominar principios. Según SQueLLA NARDUCCI, "los principios generales del Derecho nacieron para auxiliar a los jueces en el ejercicio de la función jurisdiccional, a la vez que para introducir un control que evitara las decisiones discrecionales de aquellos, operando en los casos de falta de ley que regule el caso a ser decidido-, de oscuridades o contradicciones en las leyes aplicables al caso y que el juzgador no pudiere despejar valiéndose de los métodos o elementos de interpretación de la ley; e incluso en presencia de consecuencias notoriamente injustas o inconvenientes que pudieran derivarse de la aplicación de una ley al caso que el juez debe resolver"1.

Cualquiera sea la concepción que se albergue respecto a los principios y las funciones que éstos desempeñan, es innegable que las diversas ramas que componen al ordenamiento jurídico en muchas ocasiones están informadas por principios disímiles. Desde el punto de vista del legislador, la situación recién referida genera importantes desafíos para aquellos casos en cuya resolución incidan principios informadores de ramas distintas del ordenamiento jurídico, pues, en caso que la aplicación de uno u otro principio conlleve a decisiones diametralmente opuestas, la inexistencia de reglas positivas generará inseguridad jurídica y resigna un peligroso espacio de discrecionalidad judicial.

La cuestión acerca de la titularidad de los derechos de autor referidos a obras que un trabajador cree en virtud de un contrato de trabajo se enraíza en la problemática planteada en el párrafo anterior. En efecto, si consideramos los postulados tradicionales del Derecho laboral, particularmente la teorización acerca de la causa objetiva que subyace al contrato individual de trabajo y el principio de ajenidad de los frutos o resultados del trabajo dependiente -que encuentra soporte normativo en las mismas definiciones de empleador, trabajador y contrato de trabajo, contenidas en los artículos 3 y 7 del Código del Trabajo- ${ }^{2}$, parece posible justificar

SQueLLa (2008) p. 271.

2 En adelante "СT". Para una teorización del principio de ajenidad en base a los propios conceptos de empleador y trabajador, véase IRURETA (2014), pp. 251-282. Para un panorama general, 
que la titularidad de los derechos de autor sea atribuida directamente al empleador. Por el contrario, si atendemos a ciertos postulados del Derecho de autor, concretamente a la discutida teorización de este derecho como un derecho de la personalidad ${ }^{3}$ - en tanto la creación intelectual constituye un reflejo de la individualidad del autor-y al principio de que la titularidad originaria de los derechos corresponde al autor ${ }^{4}$ - positivizado en el artículo 7 de la Ley ${ }^{\circ}$ 17.336, Ley de Propiedad Intelectual-, pareciera ${ }^{5}$ que la titularidad corresponderá siempre al trabajador.

Ante esta encrucijada es preciso tener en cuenta que la LPI contempla ciertas reglas especiales en que pueden subsumirse algunos tipos de creaciones intelectuales que se ejecutan en cumplimiento de funciones laborales. Así ocurre tratándose de obras colectivas (artículo 5, letra c de la LPI); de programas computacionales (artículo 8 , inciso $2^{\circ}$ de la LPI); de enciclopedias, diccionarios y otras compilaciones análogas (artículo 24, letra b de la LPI); de obras periodísticas (artículo 24, letra c, de la LPI); de fotografías (artículo 34 de la LPI); y de obras cinematográficas (artículo 25, de la LPI). En todos estos casos, ya sea mediante una atribución originaria o una presunción de cesión -que implica, en cambio, una atribución secundaria-, la titularidad de las facultades patrimoniales de autor corresponde al empleador ${ }^{6}$. En la misma línea, tratándose de las obras creadas por funcionarios públicos en el desempeño de sus cargos, el inciso primero del artículo 88 de la LPI, norma de amplísimo alcance, establece que " $E l$ Estado, los municipios, las corporaciones oficiales, las instituciones semifiscales o autónomas y las demás personas jurídicas estatales serán titulares del Derecho de autor respecto de las obras producidas por sus funcionarios en el desempeño de sus cargos".

Fuera de estos casos excepcionales, habrá que determinar cuál es el principio que debe aplicarse; si acaso el de ajenidad de los frutos o resultados de la actividad del trabajador -que encuentra su soporte positivo en el

véase Alonso y CASAS (2006), p. 56 y Alarcón (1986), p. 508.

3 Para una visión general de las diversas tesis acerca de la naturaleza jurídica del Derecho de autor, véase Román (2005), pp. 13-48.

4 En la doctrina nacional se refieren a este principio SCHUSTER (2009), p. 373 y URQUIETA (2013), pp. 10-12.

5 En adelante, "LPI".

6 Para una revisión más acabada de estas reglas, véase WALKER (2014), pp. 104-113, URQUIETA (2013), pp. 14-18 y SCHUSTER (2009), pp. 375-378. 
artículo 3, letras a y b y en el artículo 7 del CT- o el de la titularidad originaria del autor, que se encuentra positivizado en el artículo 7 de la LPI. Como se intentará comprobar en el segundo capítulo de este trabajo, la balanza se inclina a favor de la segunda opción, máxime si se considera que la propia Constitución Política de la República, ${ }^{7}$ en su artículo $19 \mathrm{n}^{\circ}$ 25 , atribuye al autor la titularidad del derecho sobre las creaciones intelectuales y artísticas de cualquier especie.

Ahora bien, si la regla general es que la titularidad originaria de los derechos debe atribuirse al autor, surge una segunda cuestión. En atención a que el artículo 17 de la LPı permite al titular del Derecho de autor transferir total o parcialmente sus prerrogativas patrimoniales, la segunda cuestión consistirá en precisar si el pacto de cesión anticipada de derechos que conste en un contrato individual de trabajo, en la medida en que cumpla con alguna de las formalidades establecidas en el artículo 73 de la LPI, es suficiente para que se entiendan transferidos tales derechos. La posibilidad de que el Derecho de autor sea adquirido a título derivativo está contenida en el mismo artículo 7 de la LPI, que al respecto señala: "es titular secundario del derecho el que la adquiera del autor a cualquier título".

En este trabajo nos ocuparemos de las dos cuestiones planteadas en esta introducción, a saber: 1.- La cuestión acerca de la titularidad de los derechos de autor referidos a obras que un trabajador cree en virtud de un contrato de trabajo; 2.- La cuestión acerca de si el pacto de cesión anticipada de derechos que conste en un contrato individual de trabajo, en la medida en que cumpla con alguna de las formalidades establecidas en el artículo 73 de la LPI, es suficiente para que se entiendan transferidos tales derechos.

La resolución de las cuestiones recién planteadas es particularmente útil en una sociedad como la nuestra. En efecto, el vertiginoso desarrollo de las tecnologías y de la técnica, fenómeno particularmente propio de la sociedad postindustrial y exacerbada por el sistema de producción capitalista, apareja como consecuencia que la prestación de servicios intelectuales bajo vínculo de subordinación y dependencia sea cada vez más requerida. Por lo demás, la cuestión ha sido escasamente explorada por

7 En adelante, “CPR". 
nuestra doctrina, destacando, no obstante, los ricos aportes de URQUIETA SALAZAR y SCHUSter VerGara ${ }^{8}$.

Para el correcto desarrollo de nuestro trabajo, estimamos necesario realizar previamente una síntesis de las principales tesis existentes en la doctrina acerca de la naturaleza jurídica del Derecho de autor, precisando cuál es aquella que, en nuestra opinión, recoge nuestro ordenamiento jurídico. Este ejercicio nos permitirá analizar con mayor rigor conceptual y jurídico las cuestiones que constituyen el objeto de nuestro estudio.

El estudio se dividirá en cuatro capítulos; el primero se referirá sintéticamente a las tesis acerca de la naturaleza jurídica del Derecho de autor, precisando cuál es la que parece recoger nuestro ordenamiento jurídico; el segundo presentará el conflicto entre el principio de ajenidad y la titularidad originaria del Derecho de autor, revisando algunas de las soluciones existentes en el Derecho comparado y la solución existente en nuestro ordenamiento jurídico; el tercero examinará la validez y límites de la cesión anticipada del Derecho de autor que el trabajador adquiera sobre las obras que cree en cumplimiento de sus funciones laborales; el cuarto se referirá a los alcances de dicha cesión; finalmente, se expondrán las conclusiones.

\section{SOBRE LA NATURALEZA JURÍDICA DE LOS DERECHOS DE AUTOR: ¿ PROPIEDAD INTELECTUAL, DERECHOS DE AUTOR O DERECHO DE AUTOR?}

Las diferencias de nomenclatura que pueden advertirse cuando se habla de derechos de autor no son antojadizas y obedecen en buena medida a la naturaleza jurídica que se atribuya a estos derechos. Tal como indica De Román Pérez: "la preocupación por determinar la naturaleza y el lugar que le corresponde al Derecho de autor dentro del Derecho privado aparece hacia el último tercio del siglo xix, una vez que se ha superado la etapa de los privilegios y el Derecho de autor se encuentra ya implantado en la mayoría de los ordenamientos jurídicos" ${ }^{\prime \prime}$. En este contexto, y tal como explica la

8 URquieta (2013) y SChuster (2009).

9 De Román (2005) p. 19. 
autora, en países como Francia, Portugal y España se intentó flexibilizar el concepto de propiedad al punto que amparase las especialidades de las creaciones intelectuales. En esta línea, la consecuencia natural es concebir una propiedad intelectual, que no sería sino una especie de propiedad tesis que, entre nosotros, encontraría un correlato en el artículo 584 del Código Civil ${ }^{10}$. En Alemania, en cambio, la doctrina se aleja de la idea de una propiedad especial, levantándose dos insignes tesis acerca de la naturaleza del Derecho de autor. Por una parte, Kolher considera que sobre las creaciones intelectuales existen un Derecho patrimonial exclusivo y ciertas prerrogativas morales; sólo estas últimas prerrogativas, en opinión del autor alemán, se reconducen a la categoría de los derechos de la personalidad. Así las cosas, siguiendo la concepción de Kolher, cabe hablar de derechos de autor. Por otra parte, Gierke concibe al Derecho de autor como un derecho de la personalidad cuya facultad primaria y matriz es la de disponer de la obra, explicándose a partir de ella los demás elementos de su contenido, incluidas las facultades de carácter moral y las de carácter patrimonial'1". Bajo esta concepción es más correcto hablar de Derecho de autor; una consecuencia de esta tesis es que el autor jamás podría transferir su derecho - pues los derechos de la personalidad son inalienables $-{ }^{12}$, sino únicamente autorizar a otros la ejecución de ciertos actos o hechos materiales respecto a la obra.

Ya en el siglo xx, entre los países que adscriben a la tradición continental, la ambigüedad de los textos legales perpetúa la discusión. En Francia, aun cuando la mayoría de la doctrina estima que la Ley de 11 de marzo de 1957 recoge una concepción dualista ${ }^{13}$-reflejada en la regulación separada del "Derecho moral" y del "derecho de explotación"-, el tenor de su artículo $1^{14}$ también permite sostener que la concepción recogida es la monista ${ }^{15}$. En Alemania, en cambio, aun cuando la ley de 9 de septiembre de 1965 señale en su artículo 11 que "el Derecho de autor protege los intereses intelectuales y personales del creador en relación con la obra y su

10 En adelante, "cc".

11 De Román (2005) p. 20.

12 FueYo (1990) p. 17.

13 En esta línea véase Bertrand (1991) p. 49 y Colombet (1999) p.22.

14 "Artículo 1. El autor de una obra intelectual gozará por el solo hecho de su creación de un derecho de propiedad incorporal, exclusivo yoponible a todos. Este derecho entraña atributos de orden intelectual y moral, así como de orden patrimonial, que quedarán determinados por la presente ley".

Sobre esta línea interpretativa, véase GAUTIER (1999) pp. 29-41. 
utilización" - dando pie para que la doctrina, de manera prácticamente unánime, estime que la concepción recogida es la monista-, dentro de la sección dedicada al "contenido del Derecho de autor" se separan "los derechos morales del autor" del "derecho de explotación", levantando un manto de duda ${ }^{16}$. En España, por su parte, aun cuando también la ley de 1987 distinga separe el "derecho moral" de los "derechos de explotación", la doctrina mayoritariamente estima que la concepción recogida es la monista, existiendo relativo consenso en cuanto a que el Derecho de autor contiene facultades morales y facultades patrimoniales. Con todo, aun cuando en general predomine una visión monista del Derecho de autor, ello no implica que exista acuerdo en cuanto a su naturaleza. Al respecto, tal como precisa De Román Pérez en España, existen tres posiciones: el Derecho de autor es un derecho esencialmente patrimonial, pudiendo hablarse de una auténtica propiedad intelectual; el Derecho de autor es un derecho de la personalidad; el Derecho de autor es un derecho subjetivo con características propias, no re-conducible a la categoría de derecho de la personalidad ${ }^{17}$.

La falta de uniformidad que puede observarse en la doctrina comparada genera que el tratado internacional más importante en la materia, esto es el Convenio de Berna, en cuya discusión y redacción participaron académicos con posiciones encontradas, utilice un lenguaje eminentemente descriptivo, evitando definiciones o afirmaciones que puedan implicar el recogimiento de una u otra concepción. A mayor abundamiento, el Convenio de Berna, si bien en varias normas se refiere al Derecho de autor como si estuviese unitariamente concebido ${ }^{18}$, también habla expresamente de los derechos patrimoniales y de los derechos morales ${ }^{19}$, acercándose, con esa nomenclatura, a una concepción dualista. Como indica Roselló Manzano, "el peso histórico del término francés droit moral, que determinó, no sin reticencias como se ha visto, su inclusión en el Convenio de Berna y en la mayoría de las leyes nacionales, hace que incluso en países como España, en donde predomina la concepción monista desde el punto de vista doctrinal, legislativo y jurisprudencial, se hable con frecuencia de dere-

16 De Roman (2005) p. 21.

17 De Román (2005) p. 21.

18 Así ocurre en los artículos 7 bis, 14 bis y 24 .

19 Así ocurre destacadamente en el artículo 6 bis. 
chos morales cuando posiblemente sería más adecuado hablar de facultades morales que integran el derecho subjetivo del autor sobre sus creaciones"20.

En la misma línea, el Tratado de la OMPI sobre Derechos de Autor ${ }^{21}$, si bien se refiere al Derecho de autor como si estuviese unitariamente concebido, señala en su artículo 1.3 que "Las partes contratantes darán cumplimiento a lo dispuesto en los artículos 1 a 21 y en el Anexo del Convenio de Berna.1"; en consecuencia, aunque sea por remisión, el TODA reconoce los derechos morales, pues éstos se encuentran consagrados en el artículo 6 bis del Convenio de Berna.

Comentario aparte merece el Acuerdo sobre los Aspectos de los Derechos de Propiedad Intelectual relacionados con el Comercio ${ }^{22}$, pues, acaso por la exclusión de los derechos morales que estatuye el artículo 9.1, el Derecho de autor parece concebirse unitariamente.

Trasladado el debate a nuestro país, y a fin de verificar cuál es la concepción que parece recoger nuestro ordenamiento jurídico, no sólo debe considerarse la regulación contenida en la LPI, sino también -y acaso con mayor relieve- lo establecido en el artículo $19 \mathrm{~N}^{\circ} 25$ de la CPR y en el artículo 584 del cc. Asimismo, por estar ratificados, promulgados y publicados como leyes de la República, debiesen considerarse el Convenio de Berna -ratificado y promulgado por Chile mediante Decreto Supremo $n^{\circ}$ 266, de 1975, del Ministerio de Relaciones Exteriores, y publicado en el Diario Oficial el 5 de junio de 1975-, el TODA -ratificado por Chile y promulgado el 14 de marzo de 2001 mediante Decreto Supremo $n^{\circ} 270$, de 2003, del Ministerio de Relaciones Exteriores, y publicado en el Diario Oficial el 7 de marzo de 2003-y el ADPIC - ratificado por Chile y promulgado mediante Decreto Supremo n 16, de 1995, del Ministerio de Relaciones Exteriores, y publicado en el Diario Oficial el 17 de mayo de 1995-.

El artículo $19 \mathrm{n}^{\circ} 25$ de la CPR, además de establecer que la Constitución asegura a todas las personas "el Derecho de autor sobre las creaciones intelectuales y artísticas de cualquier especie", precisa en el inciso segundo que "el Derecho de autor comprende la propiedad de las obras yotros derechos, como

20 RoselLó (2011) p. 35.

21 En adelante, "TODA".

22 En adelante, "ADPIC". 
la paternidad, la edición y la integridad de la obra, todo ello en conformidad a la ley". Aun cuando podría pensarse que la distinción entre la propiedad de las obras y otros derechos morales positiviza una concepción dualista, en realidad el inciso segundo se limita a precisar el contenido del Derecho al que se refiere el inciso primero. Por lo demás, la norma es clara al señalar que es el Derecho de autor el que comprende "la propiedad de las obras y otros derechos". De esta manera, la propiedad de las obras y los otros derechos a que se refiere la norma consisten más bien en facultades reconocidas al titular del Derecho de autor, enraizadas todas en su estructura compleja. Esta conclusión preliminar es sumamente relevante, pues el artículo $19 \mathrm{n}^{\circ} 25$, en tanto está contenido en la CPR, constituye la norma fundamental a la que debe conformarse toda interpretación de un texto legal. En este sentido, los tratados internacionales antes citados -que, por las consideraciones esgrimidas más arriba, arrojan escasa luz acerca de si el Derecho de autor tiene una estructura unitaria o dualistahan de ser interpretados a la luz de lo preceptuado en el artículo $19 \mathrm{n}^{\circ} 25$, debiendo prevalecer en consecuencia una visión monista.

A un nivel legal, el artículo 584 del cc reconoce que "las producciones del talento o del ingenio son una propiedad de sus autores", agregando que "esta especie de propiedad se regirá por leyes especiales". Esta norma, más allá de que parezca concebir al Derecho de autor como una especie de propiedad -aspecto al que nos referiremos más adelante-, también refleja un entendimiento monista, en línea con lo preceptuado por el artículo 19 $\mathrm{n}^{\circ} 25$ de la CPR.

Finalmente, cierto es que la LPI contiene normas que podrían reflejar tanto la concepción monista como la dualista. Así, por ejemplo, los artículos 1 inciso segundo, 6, 7, 8 inciso segundo, 9, 25, 48, entre otros, hablan del "Derecho de autor" reflejando la primera concepción. Por su parte, además de ciertas normas que distinguen o presuponen la distinción entre derechos patrimoniales y derechos morales - por ejemplo, los artículos 12 inciso segundo y 28-, los nombres de los capítulos IV y V del Título I, que se rubrican "derecho moral" y "derecho patrimonial, su ejercicio y limitaciones" respectivamente, parecen trasuntar una concepción dualista. En efecto, el artículo 14, primer artículo del capítulo IV, señala que "El autor, como titular exclusivo del derecho moral, tiene de porvida las siguientes facultades: 1) Reivindicar la paternidad de la obra, asociando a la misma su nombre o seudónimo conocido; 2) Oponerse a toda deformación, mutilación u otra 
modificación hecha sin expreso y previo consentimiento. No se considerarán como tales los trabajos de conservación, reconstitución o restauración de las obras que hayan sufrido daños que alteren o menoscaben su valor artístico; 3 ) Mantener la obra inédita; 4) Autorizar a terceros a terminar la obra inconclusa, previo consentimiento del editor o del cesionario si los hubiere, y5) Exigir que se respete su voluntad de mantener la obra anónima o seudónima mientras ésta no pertenezca al patrimonio cultural común"; por su parte, los artículos 17 y 18, que abren el párrafo primero del capítulo $\mathrm{V}$, disponen que "el Derecho patrimonial confiere al titular del Derecho de autor las facultades de utilizar directa y personalmente la obra, de transferir, total o parcialmente, sus derechos sobre ella y de autorizar su utilización por terceros" y que "Sólo el titular del Derecho de autor o quienes estuvieren expresamente autorizados porél tendrán el derecho de utilizar la obra en alguna de las siguientes formas: a) Publicarla mediante su edición, grabación, emisión radiofónica o de televisión, representación, ejecución, lectura, recitación, exhibición y, en general, cualquier otro medio de comunicación al público, actualmente conocido o que se conozca en el futuro; b) Reproducirla por cualquier procedimiento; $c$ ) Adaptarla a otro género, o utilizarla en cualquier otra forma que entrañe una variación, adaptación o transformación de la obra originaria, incluida la traducción; d) Ejecutarla públicamente mediante la emisión por radio o televisión, discos fonográficos, películas cinematográficas, cintas magnetofónicas u otro soporte material apto para ser utilizado en aparatos reproductores de sonido y voces, con o sin imágenes, o por cualquier otro medio. e) La distribución al público mediante venta, o cualquier otra transferencia de propiedad del original o de los ejemplares de su obra que no hayan sido objeto de una venta u otra transferencia de propiedad autorizada por él o de conformidad con esta ley".

En este escenario, la norma que a nuestro juicio entrega la pauta interpretativa es el mismísimo artículo 1, que en su inciso segundo establece que "El Derecho de autor comprende los derechos patrimonial y moral, que protegen el aprovechamiento, la paternidad y la integridad de la obra". A partir de esta norma, y en línea con lo expuesto respecto al artículo $19 \mathrm{n}^{\circ} 25$ de la CPR, se puede concluir que los derechos patrimonial y moral a que se refiere la norma, en realidad, son facultades que integran el contenido de un derecho subjetivo único. VALDÉS AlONSO, refiriéndose al artículo 2 de la Ley de Propiedad Intelectual española ${ }^{23}$-norma bastante similar

23 La norma española señala:

"Artículo 2. Contenido.

La propiedad intelectual está integrada por derechos de carácter personal y patrimonial, que atri- 
a la contenida en el artículo 1 inciso segundo de la LPI-, concluye en el mismo sentido cuando señala que "lo que el trLPI denomina derechos no son otra cosa que el elenco o haz de facultades que constituyen el objeto de un Derecho único"24. Por lo demás, los artículos 17, 18, 19 y 20 de la LPI, que regulan el denominado "Derecho patrimonial", presuponen o refieren expresamente que tal Derecho se atribuye al "titular del Derecho de autor", demostrando en consecuencia que aquél no es más que una facultad que integra a este último.

Como hemos visto, seguir una visión monista implica que el Derecho de autor sea concebido unitariamente; en este sentido, cuando la LPI se refiere al "derecho moral" y al "derecho patrimonial", en realidad está regulando las facultades morales y patrimoniales que integran un Derecho único. En consecuencia, cada vez que en lo sucesivo hablemos de Derecho de autor nos estaremos refiriendo al Derecho unitariamente concebido, sin perjuicio de las eventuales precisiones que según el caso sean necesarias.

Así las cosas, asumiendo que nuestro ordenamiento jurídico recoge una concepción monista, resulta útil indagar cuál es la naturaleza jurídica del Derecho de autor. En este sentido, menester es precisar que, aun cuando este Derecho esté consagrado como Derecho Constitucional y su imperio pueda ser tutelado por la acción de protección, no por ello debe concebirse necesariamente como un derecho de la personalidad. En efecto, aun cuando no exista acuerdo en cuanto a su naturaleza, en general se concibe a los derechos de la personalidad como aquellos consustanciales o esenciales a toda persona, emanados de su dignidad ${ }^{25}$. El Derecho de autor, en realidad, no parece ser consustancial o esencial a toda persona, sino que es reconocido precisamente a aquella que ha creado una obra intelectual-obra que, por lo demás, debe cumplir determinados requisitos para que merezca protección ${ }^{26}$. Además, una de las características que

buyen al autor la plena disposición y el derecho exclusivo a la explotación de la obra, sin más limitaciones que las establecidas en la Ley".

24 VALDÉs (2001) p. 62.

25 Para una caracterización de los derechos de la personalidad, véase FuEYo (1990) pp. 16 y 17. Para una aproximación general a la responsabilidad civil como mecanismo tutelar de los derechos de la personalidad, véase Domínguez (2009) pp. 409-423.

26 Como señala Walker Echeñique, "A diferencia de la propiedad industrial, desde sus orígenes el ámbito de aplicación del Derecho de autor no se define según el contenido de una lista taxativa sino 
usualmente se asigna a los derechos de la personalidad es la intransmisibilidad ${ }^{27}$, pues, en tanto son consustanciales al titular, se extinguen con su muerte; tal característica, por disposición de los artículos 10 y 15 de la LPI, no es predicable tratándose del Derecho de autor. Finalmente, puede agregarse que los derechos de la personalidad no tienen un objeto absolutamente externo al sujeto titular, sino ciertos aspectos derivados de su dignidad tales como su vida misma, su privacidad y su honor; en cambio, el Derecho de autor tiene por objeto una creación intelectual, que si bien refleja la individualidad del autor, debe estar expresada de determinada forma, es decir, exteriorizada en el mundo e independizada del autor ${ }^{28}$. Por todas estas razones estimamos que Lamas yerra cuando, refiriéndose a las prerrogativas morales que integran el Derecho de autor-que Lamas, acaso por la concepción dualista recogida en el ordenamiento uruguayo ${ }^{29}$, refiere como "derecho moral de autor"-, señala que "se trata de un derecho inherente a la personalidad humana y, además, personalísimo, razón por la cual su exclusivo titular es el creador, sin perjuicio de que el ordenamiento jurídico, en algunos casos, otorga a los herederos o al Estado el derecho de velar por la integridad de la obra. Es, como todos los derechos inherentes a la personalidad humana, inalienable, inembargable, imprescriptible, o sea que está fuera del comercio de los hombres" ${ }^{\prime 30}$. En nuestra opinión, ni siquiera bajo una concepción dualista, en que tendría sentido hablar de derechos morales, éstos tendrían la naturaleza de derechos de la personalidad, pues no son realmente consustanciales o esenciales a toda persona; tales derechos se reconocen únicamente a aquella persona que ha creado una obra intelectual que cumpla con los requisitos para merecer protección. Dis-

que se desprende de la aplicación de tres exigencias particulares, establecidas tanto en la ley chilena como en la regulación comparada y-especialmente-los tratados internacionales que regulan esta área del derecho. El primero de los requisitos consiste en la existencia de una expresión. El segundo requisito es la originalidad. Finalmente, la ley exige que la obra sea de la inteligencia en los dominios literarios, artísticos y científicos". WALKER (2014) p. 75.

27 Fuevo (1990) p. 17.

28 También puede verse una crítica a la concepción del Derecho de autor como derecho de la personalidad en De Román (2005) pp. 38-43.

29 La ley de derechos de autor uruguaya establece en su artículo 1:

"Artículo 1. Esta ley protege el derecho moral del autor de toda creación literaria, científica o artística y le reconoce derecho de dominio sobre las producciones de su pensamiento, ciencia o arte, con sujeción a lo que establece el derecho común y los artículos siguientes". Atendido el tenor de la norma, Lamas opina que "las creaciones intelectuales son objetos sobre los que se ejercen en forma simultánea dos derechos de diferente naturaleza, que coexisten pacíficamentey que pueden o no tener el mismo titular". Lamas (2009) p. 162.

30 LAMAS (2009) p. 162. 
tinto es el caso de la libertad de crear y difundir las artes - reconocida en nuestro sistema en la primera parte del artículo $19 \mathrm{n}^{\circ} 25$ de la CPR-, pues ésta se reconoce a toda persona por el sólo hecho de ser tal y, en ese entendido, es efectivamente consustancial a la persona.

Tampoco es plausible la tesis de que nuestro sistema jurídico conciba al Derecho de autor como una especie de propiedad, pues, aun cuando el nombre de la LPI así lo sugiera, y aun cuando se regule en ella un "Registro de Propiedad Intelectual" y se hable en algunas ocasiones de "delitos contra la propiedad intelectual", "obras de dominio ajeno", "derechos de autor y otros derechos de propiedad intelectual", lo cierto es que la regulación del Derecho de autor presenta características que lo alejan de la clásica propiedad civil. En efecto, a diferencia de la propiedad civil, el Derecho de autor -al menos en lo que respecta a las facultades patrimoniales- ${ }^{31}$ no es perpetuo, sino que, en conformidad al artículo 10, dura por toda la vida del autor y hasta por 70 años más contados desde el fallecimiento del autor. Adicionalmente, como ya se ha dicho tantas veces, el Derecho de autor recae sobre una creación intelectual, esto es, una cosa inmaterial que, tal como señala URQUIETA SALAZAR, no tiene la naturaleza de cosa corporal ni incorporal, dificultando su calificación como propiedad ${ }^{32}$. A mayor abundamiento, y siguiendo en este punto a GuZMÁn BRITO, aun cuando el artículo 584 del cc señale que "Las producciones del talento o del

31 El artículo 10, que establece que la protección que otorga la LPI "dura por toda la vida del autor y se extiende hasta por 70 años más, contados desde el fallecimiento". Tal norma no distingue entre las facultades morales y patrimoniales, por lo que podría entenderse que establece un límite temporal al Derecho de autor considerado en todo su contenido. No obstante, tal como señala Walker Echeñique, "existen otras normas que contienen normas especiales en relación con la determinación de la duración de la protección. El artículo 11 de la ley, que regula el patrimonio cultural común, establece que las obras que compongan dicho patrimonio 'pueden ser utilizadas por cualquiera, siempre que se respete la integridad y paternidad de la obra'. De lo anterior se desprende que tanto la facultad de integridad como la de paternidad subsisten después del transcurso de 7 o años contados desde el fallecimiento del autor. De lo contrario, no tendría sentido que las obras de dominio público tuviesen que respetar tanto la paternidad e integridad de la obra. Si las personas tienen el deber de respetar dichos aspectos de una obra significa que existe un derecho que exige dicho respeto, correspondiendo en este caso a los derechos morales. Asimismo, el articulo 8 o letra a), que regula los delitos contra la propiedad intelectual, establece que comete delito 'el que a sabiendas, reproduzca, distribuya, ponga a disposición o comunique al público una obra perteneciente al dominio público o al patrimonio cultural común bajo un nombre que no sea el del verdadero autor'. En conclusión, porregla general los derechos morales duran toda la vida del autor hasta los 7 a años contados desde su fallecimiento. Excepcionalmente, los derechos de paternidad e integridad tienen carácter de perpetuos". Walker (2013) p. 121. 
ingenio son una propiedad de sus autores" y agregue en el inciso segundo que "esta especie de propiedad se regirá por leyes especiales", el sentido en que se utiliza la expresión propiedad no es el sentido técnico -que, dicho sea de paso, no es otro que el contenido en el artículo 582-, sino que el de "cualidad abstracta que algo puede tener de ser 'propio' de alguien, en oposición no a 'común' sino a 'ajeno' '. ${ }^{33}$ De esta manera, cuando se habla de propiedad intelectual se denota una propiedad en sentido impropio, esto es, la titularidad de un sujeto sobre el Derecho de autor u otros derechos $\operatorname{conexos}^{34}$.

Así las cosas, atendidas las dificultades para categorizar el Derecho de autor, entendemos, siguiendo a Espín ALBA, que "el Derecho de autor es un derecho subjetivo absoluto sobre un bien inmaterial, temporalmente limitado, integrado por facultades de orden moral y patrimonial. En suma, es un derecho subjetivo absoluto de carácter sui géneris en función de su objeto"35.

El concepto que seguimos permite explicar que, aun cuando esté consagrado en la Constitución, el autor puede transferir o ceder su derecho a cualquier título. En este sentido, la transferibilidad consagrada en los artículos 7 y 73 de la LPI no es contraria al reconocimiento constitucional del Derecho de autor, pues de tal reconocimiento no se sigue que deba ser concebido como un derecho de la personalidad y, por ende, sea intransferible e intransmisible. Esta es una constatación fundamental para nuestro estudio, pues la libre transferibilidad constituye un presupuesto indispensable para sostener que un trabajador puede ceder anticipadamente a su empleador el derecho que el primero adquiera sobre una obra intelectual creada a consecuencia del cumplimiento de sus funciones laborales.

Ahora bien, tal como se desprende del encabezado del artículo 14 y del artículo 16 de la LPI, las facultades morales reconocidas al autor son personalísimas y por tal razón no pueden ser transferidas a terceros. En otras palabras, la transferibilidad del Derecho de autor no alcanza las facultades morales, las que conservará el autor durante toda su vida. Sin duda, esta limitación, justificada en la íntima vinculación entre el autory su obra,

33 GuZMÁN (2006) p. 139.

34 A una conclusión análoga arriban Alessandri, Somarriva y Vodanovic, quienes estiman que la expresión "especie de propiedad" da cuenta de una apariencia de propiedad que, en realidad, no es tal (ALESSANDRi et al [2005] pp. 32 y 33).

Espín (1994) pp. 27 y 28. 
entraña un complejo desafío dogmático, pues si el autor conserva las facultades morales aun cuando haya transferido su derecho, cabe cuestionarse si tales facultades no devienen en auténticos derechos subjetivos personalísimos. La subsistencia de la titularidad del autor de las facultades morales revive la discusión, aparentemente zanjada por el artículo $19 \mathrm{n}^{\circ} 25$ de la CPR, en cuanto a si nuestro ordenamiento jurídico sigue una concepción monista o dualista ${ }^{36}$. Como sea, por las mismas razones ya expresadas más arriba, las facultades morales, incluso siendo personalísimas, no tendrán jamás la calidad de derechos de la personalidad ${ }^{37}$.

Finalmente, otra limitación a la transferibilidad del Derecho de autor está dada por el derecho de participación, también conocido como derecho de reventa o droit de suit. Este derecho, reconocido en los artículos 36 de la LPI y 14 ter del Convenio de Berna -tratado ratificado por el Estado de Chile en virtud del Decreto Supremo $N^{\circ} 266$, del año 1975, del Ministerio de Relaciones Exteriores-, pese a tener un contenido esencialmente pecuniario, es también personalísimo ${ }^{38}$.

36 Sobre este punto, VALDÉS Alonso estima que "nada impide que las diversas facultades que integran un derecho tengan diferentes destinos, tal y como ocurre, por ejemplo, con la propiedad y el usufructo". VALDÉs (2001) p. 34. Bajo esta premisa, el Derecho de autor se puede seguir concibiendo como un derecho subjetivo único.

37 En una interpretación aparentemente distinta a la nuestra, SCHuster señala que "los derechos morales no se encuentran en el comercio, y su naturaleza inalienable, que los acerca a los derechos de la personalidad, sólo admite la transmisión por causa de muerte al cónyuge sobreviviente y a los sucesores abintestato". SCHUSTER (2009) pp. 373 y 374.

38 Para una aproximación general a este derecho y su regulación en la LPI, véase WALKER (2013) pp. 191-193. Cabe referir que el derecho de reventa tiene escasa aplicación práctica, en atención a la gravosa carga que significa para el autor probar el aumento de valor de la obra revendida. 


\section{PRINCIPIO DE AJENIDAD DE LOS PRODUCTOS DE LA ACTIVIDAD DEL TRABAJADOR Y TITULARIDAD ORIGINARIA DEL DERECHO DE AUTOR}

El principio de ajenidad de los frutos o productos de la actividad del trabajo se relaciona íntimamente con la causa objetiva del contrato de trabajo. En términos generales, la causa objetiva consiste en la cesión remunerada de los frutos que resultan del trabajo personal ${ }^{39}$. Desde otra perspectiva, si se siguiesen los postulados de la doctrina clásica de la causa ${ }^{40}$, la causa de la obligación del trabajador de prestar servicios personales bajo vínculo de dependencia y subordinación residiría en la obligación recíproca del empleador de pagar por estos servicios una remuneración determinada; a su vez, la causa de la obligación del empleador de pagar una remuneración determinada residiría en la obligación recíproca del trabajador de prestar servicios personales bajo vínculo de subordinación y dependencia. Con todo, la causa de la obligación del empleador no se agota en la mera exigibilidad de la obligación del trabajador de prestar servicios personales, sino también, por alcance, en la utilidad patrimonial derivada del cumplimiento de tal obligación. En efecto, siguiendo en este punto a Lyon Puelma, una lectura lógica de los incisos primero y segundo del artículo 1467 de nuestro Código Civil nos debiese llevar a concluir que la causa de la obligación, que debe ser real y lícita, consiste justamente en el motivo que induce a la celebración del contrato; este motivo, que es abstracto y objetivo, se refiere al resultado final al que se aspira arribar con la ejecución del contrato ${ }^{41}$; de esta manera, la causa de la obligación de remunerar está mediada no solamente por la obligación recíproca del trabajador de prestar servicios personales bajo vínculo de subordinación y dependencia, sino también por la finalidad que persigue el empleador en el contrato de trabajo, que no es otra que aprovecharse de los frutos y productos provenientes de la actividad laboral.

Como sea, aun cuando pueda problematizarse, la noción de causa objetiva sirve para explicar que los frutos derivados de la prestación de servicios personales por parte del trabajador sean atribuidos originaria y directamente al empleador. Como señala VALDÉs AlONSO, "más concretamente

39 Alonso y Casas (2006) p. 38.

40 Sobre esta doctrina, véase VIAL (2003) pp. 191-193.

41 LYON (2006) pp. 76o-769. 
- desde la perspectiva de que el trabajador nunca es propietario originario de los frutos de su trabajo (y por tanto no puede cederlos)-, la causa del contrato, en este plano objetivo, sería la atribución originaria al empresario de la titularidad de los frutos a cambio del salario" 42 . En el ámbito nacional, IRURETA URIARTE ha entendido que "la dependencia laboral termina distinguiéndose por una disposición general del trabajador para prestar servicios dentro del ámbito organizativo del empleador. Este mismo hecho liga la dependencia con la ajenidad, ya que en definitiva la inserción dentro del círculo rector de otra persona deja al descubierto que el resultado de los servicios efectuados por el trabajador va a ser utilizado por el empleador y se integrará necesariamente dentro del patrimonio de éste" ${ }^{43}$. Según el mismo autor, la ajenidad puede vislumbrarse también en la definición de empleador contenida en el artículo 3, letra a del $\mathrm{CT}^{44}$. En efecto, si bien la norma no permite una conceptualización acabada de la figura del empleador, pone el acento en la ajenidad al señalar que empleador es "la persona natural o jurídica que utiliza los servicios intelectuales o materiales de una o más personas en virtud de un contrato de trabajo".

En síntesis, tal como señala URQUIETA SALAZAR, "uno de los principales efectos jurídicos del contrato de trabajo es que el empleador se convierte en el beneficiario ab initio, es decir de forma inicial u originaria, de los resultados, o de los frutos como los llaman algunos autores, de los servicios encomendados" 45 . A su vez, la misma nota de ajenidad justifica que los riesgos de la actividad empresarial sean soportados íntegramente por el empleador, de manera que la remuneración a que tiene derecho el trabajador no dependa jamás del éxito o fracaso de aquella actividad.

Ahora bien, cuando la obligación del trabajador consiste en la prestación de servicios creativos, el principio de ajenidad encuentra un poderoso y preciso contrapeso. En efecto, si se aplicara el principio de ajenidad, se debería atribuir originaria y directamente al empleador la titularidad del Derecho de autor sobre toda obra creada por el trabajador en cumplimiento de sus funciones, a fin de que el primero pueda explotarla y desarrollar normalmente su actividad económica; no obstante, si entre las

42 VAldÉs (2OO1) p. 95.

43 IRureta (2014) p. 269.

44 Ibíd., pp. 265-267.

45 URQUiETA (2013) p. 4. 
finalidades de un estatuto de Derecho de autor se encuentran "asegurar a los autores una protección adecuada para los resultados de su creación y estimular la actividad creativa" ${ }^{\prime 6}$, la aplicación irrestricta del principio de ajenidad se torna ciertamente problemática. A mayor abundamiento, si el Derecho de autor se funda en el acto de creación intelectual ${ }^{47}$, la atribución de la titularidad del derecho al autor mismo se convierte, cuando no en una regla absoluta, cuanto menos en un mandato de optimización, esto es, un estándar que ha de ser observado en la mayor medida posible en tanto constituye una exigencia de la justicia, la equidad o alguna otra dimensión de la moralidad ${ }^{48}$. De esta manera, en tanto el principio de ajenidad también constituye un mandato de optimización, la cuestión de la titularidad de los derechos de autor sobre las obras creadas por trabajadores en cumplimiento de sus funciones entraña una colisión entre dos principios que informan a ramas distintas del ordenamiento jurídico y cuya solución ideal, en nuestra opinión, no es sino la existencia de una regla positiva. Esta colisión, dicho sea de paso, no sólo se presenta cuando el trabajador, entre las diversas funciones que asume, tiene al menos una tendiente a la creación de obras pertenecientes a los dominios literarios, artísticos y científicos, la colisión también se presenta -y alcanza su mayor relieve práctico- cuando se trata de un trabajador creativo, esto es, un trabajador cuyas funciones tiendan íntegramente a la creación de obras pertenecientes a los dominios literarios, artísticos y científicos.

En Derecho comparado, la solución no es unívoca ${ }^{49}$.

46 LIPSZYC (2006) p. 125.

47 Este entendimiento está contenido en los parágrafos 5 y 6 del capítulo 2 de la Carta del Derecho de autor, la cual fue adoptada el 26 de septiembre de 1956 en Hamburgo por el XIX Congreso de la Confederación Internacional de Sociedades de Autores y Compositores (CISAC). “5. El Derecho de autor se funda en el acto de la creación intelectual.

Tiene su origen en la naturaleza misma de las cosas. No puede pues encontrar en la ley sino su reglamentación, ya que su existencia no debe nunca subordinarse a formalidades de orden constitutivo. 6. El título justificativo del Derecho de autor, que reside en el acto de la creación intelectual, radica únicamente en la persona física de su o de sus creadores, cuando este derecho nace.

Una persona moral nunca puede ser considerada como el titular original del Derecho de autor en una obra del espíritu. Importa desechar, como inadmisible, el concepto del autor como simple asalariado de una empresa industrial, a la cual la obra revertiría en derecho como un producto cualquiera".

48 DWORKIN (1984) p. 72.

49 Para un panorama general, véase URIBE (2007) pp. 6o-66. 
Como señala Montora Mora, citada por Uribe Corzo, "Especialmente en el "Copyright" (sistema anglosajón y americano), así como en Holanda, Japón y Turquía, los derechos de autor nacen en la persona del empresario, lo que se determinó mediante Ley. Tales diferencias en el ámbito internacional son consecuencia del hecho de que los convenios internacionales para la protección de las obras literarias y artísticas han omitido regular la posición del creador empleado, por lo que cualquier país, aunque puede haber ratificado tales convenios, es libre de considerar directamente al empresario como autor de las obras creadas por el empleado" ${ }^{\prime 50}$.

En otra línea, en algunos ordenamientos que adscriben a la tradición continental se entrega la determinación de la titularidad a la autonomía privada, contemplándose, a falta de pacto expreso, una presunción simplemente legal de la cesión de los derechos patrimoniales a favor del empleador. En el ámbito latinoamericano, así ocurre en Guatemala, Honduras, Panamá, Venezuela, Ecuador y Perú ${ }^{51}$. Fuera de nuestro continente, un caso particularmente paradigmático es el de España, en que el artículo $51 \mathrm{~N}^{\circ} 2$ de la LPI contempla una presunción de la cesión de los derechos de explotación, precisando que esta cesión es exclusiva y tiene solamente el alcance necesario para el ejercicio de la actividad habitual del empresario. Esta norma parece reflejar una sana medida de equilibrio entre los intereses del empleador y los del trabajador, conciliando la colisión entre el principio de ajenidad y el principio de titularidad originaria del autor ${ }^{52}$. Con todo, conviene precisar que la cesión, ya sea convencional o legal, confiere la titularidad secundaria, reconociéndose, en consecuencia, que la titularidad originaria pertenece siempre al autor. De esta manera, aun cuando exista una cesión, las prerrogativas morales y el eventual derecho de participación pertenecerán siempre al autor.

Por su parte, otros ordenamientos jurídicos que adscriben a la tradición continental, acaso fundados en la idea de que la obra constituye un reflejo de la personalidad del autor, no contemplan reglas especiales que atribu-

50 URIBE (2007) p. 60.

51 Ibid., p. 61.

52 Sobre este tema, véase Rodríguez y Álvarez (2004) pp. 43-56. 
yan la titularidad al empleador, tornándose aplicables las reglas generales que atribuyen la titularidad al autor. Así ocurre, por ejemplo, en Argentina, Suecia y Colombia ${ }^{53}$.

En el caso de Francia, si bien tampoco existe una regla especial que atribuya la titularidad al empleador, la jurisprudencia ha sostenido sistemáticamente que el contrato de trabajo contiene implícita la cesión de las prerrogativas patrimoniales sobre las obras creadas por el trabajador en cumplimiento de sus funciones y cuya explotación efectivamente contribuya al desarrollo de la actividad económica del empleador ${ }^{54}$. Por su parte, la titularidad de las prerrogativas morales se mantiene siempre en el autor.

53 URIBE (2007) p. 61.

En la Ley 11.763 de la República de la Argentina, que fija el Régimen Legal de la Propiedad Intelectual, ante la inexistencia de una regla que atribuya la titularidad al empleador, la regla general se encuentra en el artículo 5 inciso primero, que establece que: "La propiedad intelectual sobre sus obras corresponde a los autores durante su vida y a sus herederos o derechohabientes hasta setenta años contados a partir del 1 de enero del año siguiente al de la muerte del autor". En la ley sueca, esto es, la Act on copyright in literary and artistic works, ante la inexistencia de una regla que atribuya la titularidad al empleador, la regla general está establecida en el artículo 1, que señala: "Anyone who has created a literary or artistic work shall have copyright in that work, regardless of whether it is 1. a fictional or descriptive representation in writing or speech, 2. a computer program, 3. a musical or dramatic work, 4. a cinematographic work, 5. a photographic work or another work of fine arts, 6. a work of architecture or applied art, 7. a work expressed in some other manner. Maps and other works of a descriptive nature executed as drawings, engravings, or in a three-dimensional form, shall be considered as literary works. What is prescribed in this Act concerning computer programs shall mutatis mutandis apply also to preparatory design material for computer programs". En Colombia, la Ley n 23 de 1982, que establece el Régimen general de derechos de autor, no contempla en su artículo 4 al empleador como titular del Derecho de autor de la obra creada a consecuencia del cumplimiento de las funciones laborales del trabajador. Tal norma señala: "Son titulares de los derechos reconocidos por la ley: a) el autor de su obra; b) el artista, intérprete o ejecutante, sobre su interpretación o ejecución; c) el productor, sobre su fonograma; d) el organismo de radiodifusión sobre su emisión; e) los causahabientes, a título singular o universal, de los titulares anteriormente citados; $f$ ) la persona natural o jurídica que, en virtud de contrato, obtenga por su cuenta y riesgo la producción de una obra científica, literaria o artística realizada por uno o varios autores en las condiciones previstas en el artículo 20 de esta ley". Conviene tener presente que el artículo 20 regula una hipótesis de obra colectiva; tal norma señala "Cuando uno o varios autores, mediante contrato de servicios, elaboren una obra según plan señalado por persona natural o jurídica y por cuenta y riesgo de ésta, sólo percibirá, en la ejecución de este plan, los honorarios pactados en el respectivo contrato. Por este acto se entiende que el autor o autores transfieren los derechos sobre la obra, pero conservarán las prerrogativas consagradas en el artículo zo de la presente ley, en sus literales a) y b)".

54 Ibid., p. 63. 
Como puede apreciarse, la decisión acerca de la titularidad del Derecho de autor corresponde a cada Estado, existiendo diversas soluciones en Derecho comparado. En nuestro Derecho, tal como indica URQUIETA SALAZAR, "la ley no regula en forma sistemática y general el problema de la titularidad de los derechos de autor cuando la creación fue efectuada como consecuencia del trabajo por cuenta ajena, limitándose a señalar ciertos casos, precisos y excepcionales, en los cuales la obra será atribuida al empleador" ${ }^{\prime \prime 5}$. Fuera de estos casos excepcionales, la norma fundamental es el artículo 7 de la LPI, que establece que "Es titular original del derecho el autor de la obra. Es titular secundario del derecho el que la adquiera del autor a cualquier título". En palabras de Schuster Vergara, "Habiendo establecido el legislador regímenes específicos para las obras intelectuales creadas bajo contrato de empleo, y previsto en ellos la titularidad o adquisición o ejercicio de tales derechos por los empleadores, no cabe sino afirmar que en los demás casos no hay titularidad originaria ni presunción de cesión de derechos, los que permanecen en el autor, sujeto a las reglas generales" ${ }^{\prime \prime 6}$.

En suma, en nuestro ordenamiento jurídico, la regla general es que la titularidad originaria de las obras creadas en cumplimiento de funciones laborales sea atribuida al autor, conclusión que se refuerza si se considera el tenor del artículo $19 \mathrm{n}^{\circ} 25$ de la CPR. La norma constitucional es bastante clara al señalar que la Constitución asegura a todas las personas "el derecho del autor sobre sus creaciones intelectuales y artísticas de cualquier especie, por el tiempo que señale la ley y que no será inferior al de la vida del titular". En consecuencia, el derecho corresponde al autor, es decir, a "la persona natural que crea la obra literaria, artística o científica que es objeto de protección legal"57.

Así las cosas, nos sorprende que SChuster Vergara, luego de reconocer que la regla general es que la titularidad originaria sea atribuida al autor, señale que "sin perjuicio de ello es evidente que el empleador puede realizar una explotación de la obra, ya que ese es el objeto del contrato de trabajo. Por tanto, queda asegurado el ejercicio de los derechos patrimoniales para que la empresa que contrató al autor pueda utilizar la obra de acuerdo a su giro (...) El empleador, conforme a la definición del Código del Trabajo (artículo

\footnotetext{
55 URQUieta (2013) p. 9.

56 SCHUSTER (2009) p. 379.

57 WALKer (2013) p. 103.
} 
3, a), es la persona natural o jurídica que utiliza los servicios intelectuales o materiales de una o más personas, en virtud de un contrato de trabajo, y en este 'uso' evidentemente se encontrarán las obras producidas por los autores trabajadores, como resultado de la tarea creativa para la que fueron contratados $^{\prime \prime 58}$. Si bien el planteamiento de SCHUSTER VERGARA parece plausible y justificado desde la perspectiva de la causa objetiva del contrato de trabajo y el principio de ajenidad laboral, estimamos que no se concilia con nuestro ordenamiento jurídico. En efecto, si se hace una lectura conjunta de los artículos 7, 17 y 18 de la LPI, para que el empleador pueda explotar económicamente la obra creada por el trabajador se requiere cuanto menos la autorización del autor; luego, en tanto los artículos 19 y 20 de la LPI exigen que la autorización sea expresa y determinada ${ }^{59}$, no creemos ajustado al Derecho positivo inferir una autorización tácita en base al interés que el empleador alberga en la ejecución del contrato de trabajo ni tampoco con base en la definición legal de empleador. En realidad, aunque parezca poco equilibrado para los intereses del empleador, bajo las reglas que nos rigen, si este sujeto desea explotar económicamente la obra -como legítima y probablemente ocurrirá- será necesario que el contrato de trabajo contenga una cláusula de cesión o autorización que cumpla con todas las exigencias legales ${ }^{60}$.

58 SCHUSTER (2009) pp. 379 y 380.

59 Sobre los requisitos de la autorización, véase WALKER (2013) pp. 185-187.

60 Una alternativa a la estipulación de una cláusula de cesión o autorización anticipada consiste en que, en conformidad al artículo $10 \mathrm{~N}^{\circ} 3$ del CT, el trabajador asuma como una de sus funciones la entrega de información, instrucciones, consejos y asesoramientos suficientes al empleador, a fin de que éste pueda ejecutar correctamente una o más técnicas o procesos que han permitido a aquél crear una obra en los dominios literarios, artísticos o científicos. En otras palabras, una de las funciones asumidas por el trabajador podría consistir en la transferencia know-how. Sobre este punto es importante tener presente que el know-how no necesariamente se limita al conocimiento con carácter reservado de técnicas susceptibles de aplicación industrial; basta con que las técnicas sean susceptibles de explotación empresarial y tengan un valor económico, lo que perfectamente puede predicarse de las técnicas utilizadas para crear una obra en los dominios literarios, artísticos o científicos (sobre estos tópicos, véase BeNAVENTE [2005], pp. 201-207). Asílas cosas, la adquisición de know-how le será útil al empleador en la medida en que el conocimiento entregado por el trabajador sea aprovechado por la empresa mediante otros trabajadores, quienes ejecuten la técnica o proceso correctamente y creen nuevas obras que, por carecer de originalidad, no den lugar a nuevos derechos de autor, pudiendo ser explotadas directamente por el empleador. Ahora bien, la transferencia de know-how por parte de un trabajador no implica de ninguna forma una cesión o autorización al empleador para utilizar la obra que aquél cree y que esté protegida por un Derecho de autor, sino que simplemente permite a éste que, mediante otros trabajadores, ejecute la técnica informada y pueda así crear nuevas obras no originales, las cuales podrá 
En este contexto, la cuestión de la naturaleza jurídica del Derecho de autor, abordada ya en el capítulo anterior, es fundamental para efectos de predicar la licitud o ilicitud de las cláusulas de cesión anticipada, pues si se le concibe como un derecho subjetivo absoluto integrado por facultades morales y patrimoniales, la cláusula de cesión anticipada, en la medida en que no comprenda las facultades morales y de participación -que son personalísimas-, no sería per se ilícita. A mayor abundamiento, en tanto el Derecho de autor es un derecho sui géneris diverso a los denominados derechos de la personalidad, si en el contrato de trabajo se pacta una cláusula de cesión anticipada no existiría allí ninguna vulneración al artículo $19 \mathrm{n}^{\circ} 25$ de la CPR, pues tal norma únicamente garantiza al autor la titularidad originaria del derecho, sin impedir su enajenación. Por lo demás, la transferibilidad de las prerrogativas patrimoniales que integran el Derecho de autor no solamente está reconocida expresamente en el artículo 17 de la LPI, sino también en el artículo 17.7.2 (a) del Tratado de Libre Comercio suscrito entre Estados Unidos y Chile. Esta última norma establece que "cada parte dispondrá que para el Derecho de autory derechos conexos: (i) cualquier persona propietaria de cualquier derecho económico, es decir, no de un derecho moral, podrá, libre y separadamente, transferir tal dere-

explotar directamente en tanto no están protegidas por derechos de autor; no obstante, si otro trabajador, a la hora de ejecutar la técnica, crea una obra en que se vea reflejada su propia personalidad, esto es, una obra original, tal trabajador adquirirá sobre esa obra el correspondiente Derecho de autor, estándole vedado al empleador hacer explotación de ella sin la debida cesión o autorización. Respecto al umbral de originalidad que requiere una obra para ser protegida mediante Derecho de autor, WALKER ECHEÑIQUE expone que "La doctrina ha señalado que una obra va a ser considerada original cuando tenga una individualidad, incluso en aquellos casos en que los elementos que le den ese carácter sean mínimos. Por lo mismo, el requisito de la originalidad no debe satisfacer estándares muy exigentes sino que se satisface en la medida que la obra tenga características mínimas que la doten de una individualidad". WALKER (2013) p. 79. La franquicia, por su parte, si bien se alza como otra alternativa interesante, presupone que las partes sean jurídicamente independientes, exigencia que ciertamente no se cumple en una relación laboral, en la cual el trabajador presta servicios personales bajo vínculo de subordinación y dependencia. A mayor abundamiento, resulta natural exigir o presuponer que el franquiciante sea un comerciante, pues la licencia (de marca, otros signos distintivos, nombre comercial, patentes, modelos de utilidad, derechos de autor y know-how) y el apoyo técnico otorgados por éste permiten al franquiciado desarrollar la actividad económica que habitualmente desarrolla o ha desarrollado el franquiciante; por su parte, también resulta natural exigir o presuponer que el franquiciado sea un comerciante, pues la finalidad que persigue con la celebración y ejecución del contrato es justamente desarrollar una actividad económica y obtener un lucro en tal ejercicio. Se trata, en definitiva, de un contrato que tiene la calidad de comercial para ambas partes; además, este contrato crea diversas obligaciones para el franquiciante que van mucho más allá de la mera prestación de servicios personales bajo vínculo de subordinación y dependencia. Sobre este tema, véase HERNANDO (2000) p. 45. 
cho mediante un contrato; y (ii) cualquier persona que haya adquirido o sea propietario de tales derechos económicos en virtud de un contrato, incluidos los contratos de empleo que implican la creación de obras, interpretación o ejecución ofonogramas, podrá ejercer tales derechos a nombre propio y gozar plenamente de los beneficios que de ellos se deriven". Descontados los casos excepcionales en que la LPI atribuye originariamente el Derecho de autor al empleador o presume la cesión, la única forma de que el empleador pueda ser considerado titular secundario del derecho en virtud del contrato de trabajo mismo es admitiendo la validez de la cláusula de cesión anticipada contenida en éste.

Lo expuesto hasta este punto no implica, empero, que toda cesión anticipada contenida en un contrato de trabajo sea perfectamente lícita; como veremos a continuación, la cesión no solamente debe constar en instrumento público o privado autorizado ante notario -artículo 73 de la LPI-, sino que está sujeta a diversas limitaciones.

\section{VALIDEZ Y LÍMITES DE LA CESIÓN ANTICIPADA}

Siguiendo a WALKER ECHeÑIQUE, "en principio no existen limitaciones para que el titular originario del Derecho de autor pueda transferir sus derechos a un tercero, constituyéndose como titular secundario. Asimismo, dicho titular no debería tener restricciones para transmitir sus derechos de autor, incluso constituyendo legatarios" 61 . La autora agrega posteriormente que "la única restricción que impone la ley a la libertad para transferir los derechos se relaciona con los derechos morales. La lpi establece que los derechos morales 'son inalienables y es nulo cualquier pacto en contrario'" 62 .

La libre transferibilidad está reconocida contundentemente en el artículo 17 de la LPI, que permite al titular del Derecho de autor transferir total o parcialmente sus prerrogativas patrimoniales.

No obstante, en el tema que nos ocupa surge la siguiente cuestión: no habiéndose creado nada aún por el trabajador, ¿puede ser objeto de una

61 WALKer (2013) p. 116.

62 Ibid., p. 117. 
cesión anticipada el derecho que el trabajador adquiera cuando efectivamente cree una obra de la inteligencia que cumpla con los requisitos legales? Se trata, en términos simples, de una cesión sobre una cosa que no existe pero se espera que exista, cosa que, a la luz del artículo 1461 del CC, puede ser perfectamente objeto de un acto o declaración de voluntad. Tal como señala Domínguez ÁGUILA, "el derecho impide negocios jurídicos cuyo objeto sea absolutamente imposible, de acuerdo con la previsión normal. Cosas que no existan al momento de la declaración de voluntad, pero que se espera razonablemente que existan, pueden ser objeto de negociación y, por lo tanto, pueden constituir el objeto de un negocio (arts. 1461 inc. 1 y 1813). Por tanto, una cosa futura puede perfectamente ser materia de negociación y aun puede serlo la sola expectativa de que llegue a existir". ${ }^{3}$ En definitiva, la eficacia de la cesión dependerá de que efectivamente el trabajador cree una obra a consecuencia del cumplimiento de sus funciones; en tal escenario, tan pronto se radique en el patrimonio del trabajador el respectivo Derecho de autor, la cesión producirá sus efectos, transfiriéndose el derecho al empleador ${ }^{64}$.

En realidad, siguiendo a URQUIETA SALAZAR, el problema no reside tanto en que la cosa sea real -como tampoco en su clara comerciabilidad-, sino en su determinabilidad. En palabras del autor recién citado, "si bien, de conformidad a las reglas generales en materia contractual, el objeto de una declaración de voluntad puede recaer en una cosa que no exista pero se espera que exista, como es el caso de las obras que el trabajador vaya a crear durante la vigencia del vínculo laboral, estas deben quedar determinadas al menos en cuanto a su género"65.

En nuestra opinión, la cuestión sobre la determinabilidad anticipada de la obra creativa se vincula íntimamente con el fundamento del reconocimiento y protección del Derecho de autor ${ }^{66}$. En efecto, si se estima que el Derecho de autor se funda en un acto de creación intelectual que refleja la personalidad del autor, tal acto, único e irrepetible, difícilmente se podría determinar anticipadamente. Con todo, esta dificultad nos parece más retórica que real, pues si la función en virtud de la cual el trabajador

63 Domínguez (2012) p. 131.

64 Se trata, en definitiva, de una cesión sujeta a la condición suspensiva de que el Derecho de autor efectivamente nazca. VIAL (2003) pp. 159-160 y BARCIA (2007) p. 84.

65 URquieta (2013) pp. 11 y 12.

66 Para una visión general sobre esta cuestión, véase WALKER (2013) pp. 29-35. 
crea una obra está claramente determinada en el contrato de trabajo, no debiese existir mayor embrollo en admitir la cesión anticipada del Derecho de autor que recaiga sobre esa obra. Por lo demás, la determinación de las funciones laborales debe alcanzar el mayor grado de especificidad que sea posible, pues sólo así se garantiza que el empleador no se extralimite en el ejercicio de su poder de dirección. En efecto, tanto la doctrina como la jurisprudencia judicial y administrativa ${ }^{67}$ están contestes en que la determinación clara y precisa de las funciones del trabajador, exigida por el artículo $10 \mathrm{n}^{\circ} 3$ del $\mathrm{CT}$, es necesaria para delimitar el poder de dirección reconocido por ley al empleador. En este sentido, una cláusula que establezca un quehacer creativo demasiado amplio puede exponer al trabajador a una sustantiva merma de sus derechos fundamentales ${ }^{68}$. Si a tal cláusula de quehacer inventivo amplio se le agrega una cláusula de cesión anticipada de derechos de autor, se expone además al trabajador creativo a una sustantiva merma de los derechos que le confiere la LPI.

Así las cosas, la determinación de las funciones laborales, que debe alcanzar el mayor grado de especificidad que sea posible, sirve para delimitar la naturaleza y el género de las obras que el trabajador creará. De ahí que, en nuestra opinión, se cumpla suficientemente con el requisito de determinación a lo menos genérica exigido por el artículo 1461 del Cc $^{69}$.

67 Conforme a los dictámenes no 2.302/129, 3.05.99; 1.115/57, 25.02.94, y 4.510/214, 5.08.94, "La finalidad o intención del legislador al obligar a las partes a determinar en el contrato de trabajo la naturaleza de los servicios fue, conforme lo ha reiterado la doctrina de esta Institución, la de dar certeza y seguridad a la relación laboral respectiva, puesto que, a través de esta exigencia, el dependiente conoce la labor específica que debe cumplir, y el empleador los servicios que le requerirá, propósito éste que se cumple si la determinación de los mismos se hace en los términos concretos señalados precedentemente".

68 En un sentido similar, a propósito de las invenciones en servicio, véase SIERRA (2011) pp. $175^{-177}$.

69 Otro problema interesante consiste en precisar si los derechos de autor cedibles se refieren únicamente a aquellas creaciones que sean fruto directo del cumplimiento de las funciones asumidas por el trabajador en el contrato de trabajo o se pueden extender también a otras obras que, sin estar directamente relacionadas con las funciones del trabajador, hayan sido "realizadas con la técnica o medios del empresario y/o con la experiencia o los conocimientos adquiridos por el trabajador en su puesto de trabajo". RodríGuez y Álvarez (2004) p. 31. A este respecto, y admitiendo la posibilidad de que la cesión se pacte de manera anticipada en el contrato de trabajo, conviene tener presente que, salvo que exista un contrato o convenio colectivo aplicable, la fijación del contenido del contrato individual de trabajo, si bien está sujeta a límites infranqueables, es generalmente realizada por el empleador. En efecto, es pacífica la calificación del contrato de trabajo como un contrato dirigido, en tanto es el propio legislador el que establece un contenido mínimo e irrenunciable tendiente a resguardar una medida de equilibrio entre los intereses del empleador y del trabajador; no obstante, en todo aquello 
En suma, la cesión anticipada recae sobre una cosa real, comerciable y determinada genéricamente. Es real pues efectivamente se espera que el derecho exista; es comerciable en tanto el mismo artículo 7 de la LPI admite la posibilidad de que el derecho se radique en el patrimonio de diversas personas, sea originaria o derivativamente; y es determinada genéricamente toda vez que el derecho que se cede anticipadamente recae sobre una obra que se creará en virtud del cumplimiento de funciones laborales claramente determinadas. Luego, el objeto será lícito en la medida que la cesión se refiera únicamente a las prerrogativas patrimoniales que integran el Derecho de autor. Las prerrogativas morales y el derecho de participación, en cambio, no se transferirán jamás, siendo nula la cesión a este respecto, tal como puede desprenderse de los artículos 16 y 36 de la LPI y 1466 del cc.

Con todo, debe tenerse presente que la LPI, para efectos de la autorización que el titular del Derecho de autor confiera a un tercero para utilizar la obra de alguno de los modos y por alguno de los medios que establece la propia ley, exige que ésta sea expresa -artículo 19-y específica -artículo 20, inciso segundo-. Según el texto legal, la especificidad se traduce concretamente en "precisar los derechos concedidos a la persona autorizada, señalando el plazo de duración, la remuneración y su forma de pago, el número mínimo o máximo de espectáculos o ejemplares autorizados o si son ilimitados, el territorio de aplicación y todas las demás cláusulas limitativas que el titular del Derecho de autor imponga".

Cabe preguntarse si estas exigencias, que la ley establece explícitamente para la autorización, son también extrapolables a la cesión. URQUIETA SALA-

no regulado por ley, el contenido del contrato de trabajo será generalmente predispuesto por el empleador, subsistiendo un espacio que podría generar, en perjuicio del trabajador, desequilibrios importantes entre los derechos, obligaciones, cargas y riesgos que el contrato genera para las partes. De esta manera, ante la falta de una norma especial de carácter imperativo, resulta cuanto menos problemático entregar por entero a la autonomía privada la determinación de las obras cuyos derechos de autor el trabajador cede anticipadamente al empleador, pues es de presumir que este último estará tentado en predisponer una cláusula de cesión cuyos términos sean lo más amplios posible. En nuestra opinión, la cláusula que extienda la cesión a derechos de autor que el trabajador adquiera sobre obras que se creen más allá del cumplimiento de sus funciones laborales, contraviene las exigencias de la buena fe y genera, en perjuicio del trabajador, un desequilibrio importante. Tal cláusula, en tanto se aparta del orden público y de las buenas costumbres, es nula absolutamente por adolecer de objeto ilícito. 
ZAR parece concluir en sentido afirmativo cuando afirma que "para que una cláusula del contrato de trabajo, en virtud de la cual se cedan las obras que el trabajador creará durante la prestación de sus servicios, será necesario que cumpla en forma estricta con los requisitos de ser expresa y específica y por lo tanto deberá señalar qué tipo de obras serán creadas y los derechos que van a cederse, plazo, remuneración y forma de pago, número mínimo y máximo de espectáculos o ejemplares autorizados o si son ilimitados, el territorio de aplicación y todas las demás cláusulas limitativas que el titular del Derecho de autor imponga"70. En un sentido similar, SCHUSTER VERGARA señala que "la cesión de los derechos de autor requiere de un acto específico en el que se manifieste la voluntad del autor, debiendo precisar claramente las obras que son objeto de la convención, entre ellos, los derechos patrimoniales concedidos, el precio de la cesión, y las demás estipulaciones que en el ámbito de propiedad intelectual son pertinentes, como es el caso de la posibilidad de fragmentar territorialmente la cesión, y también definir si la cesión se realiza por todo el término de protección de la obra o por un plazo menor"71.

Compartimos las opiniones de Urquieta Salazar y Schuster Vergara en cuanto a la necesidad de especificar las prerrogativas patrimoniales que se ceden y la posibilidad de establecer un límite temporal, un límite territorial y determinadas condiciones y límites para la explotación de una obra. En cuanto a la remuneración, en cambio, estimamos que la cesión está suficientemente retribuida en la misma remuneración que se pacta en el contrato de trabajo como contrapartida de la prestación de servicios personales bajo vínculo de subordinación y dependencia. En realidad, la cesión anticipada tiende a atribuir derivativamente al empleador el aprovechamiento de eventuales frutos de la actividad del trabajador, finalidad que, desde la perspectiva del principio de ajenidad, se encuentra totalmente justificada. En efecto, el interés originario y legítimo que el empleador alberga en la ejecución del contrato de trabajo por parte del trabajador creativo es justamente aprovecharse de la creación en el marco de su actividad económica habitual. Se ha llegado incluso a decir que, tratándose de creaciones asalariadas, la causa objetiva del contrato de trabajo reside en "la cesión remunerada de los derechos de explotación de la obra creada"72.

70 URQUieta (2013) p. 14.

71 SCHUSter (2009) p. 374.

72 Rodríguez y Álvarez (2004) p. 34. 
En Colombia, cuya Ley de Propiedad Intelectual también atribuye originariamente la titularidad del derecho al autor, "tanto la jurisprudencia como la doctrina consideran que el salario que recibe el trabajador como contraprestación directa por su labor constituye también la remuneración por la cesión de los derechos sobre la obra"73.

En síntesis, estimamos que, en conformidad al artículo $10 \mathrm{~N}^{\circ} 4$ del $\mathrm{CT}$, a la hora de determinar el monto de la remuneración del trabajador se podrá -y será recomendable- establecer que ésta es correlativa tanto a la prestación misma de servicios personales bajo vínculo de subordinación y dependencia, como a la cesión de los derechos de autor que el trabajador adquiera sobre las obras creadas en cumplimiento de sus funciones laborales.

Ahora bien, en tanto el contrato de trabajo es conmutativo, debiera existir cierta medida de equilibrio entre, por una parte, la remuneración, y, por la otra, la prestación de servicios personales bajo vínculo de subordinación y dependencia y la cesión anticipada del Derecho de autor. En términos generales, la conmutatividad exige que al momento de la celebración del contrato exista la posibilidad de prever, en un margen razonable, cuáles son los beneficios económicos que el contrato acarreará a cada parte. De esta manera, si los beneficios derivados de la adquisición y utilización del Derecho de autor por parte del empleador van más allá de los márgenes razonables que éste ha previsto o podido prever al momento de la celebración del contrato, surge la cuestión de si el trabajador puede solicitar la revisión de la remuneración. La determinación de los límites territoriales en que el empleador podrá explotar la obra ciertamente será clave para efectos de prever los márgenes razonables de beneficios y la presencia o ausencia de equilibrio. En España, el artículo 47 de la LPI señala que "Si en la cesión a tanto alzado se produjese una manifiesta desproporción entre la remuneración del autory los beneficios obtenidos por el cesionario, aquél podrá pedir la revisión del contrato y, en defecto de acuerdo, acudir al Juez para que fije una remuneración equitativa, atendidas las circunstancias del caso. Esta facultad podrá ejercitarse dentro de los diez años siguientes al de la cesión". En nuestro país, lamentablemente, no existe una norma en tal sentido y, en atención al escaso desarrollo jurisprudencial de aquellas figuras 
que tienden a la protección del equilibrio contractual ${ }^{74}$-tales como la revisión por excesiva onerosidad sobreviniente, la rescisión por violencia económica, la nulidad por cláusulas abusivas, entre otras-, parece improbable que una pretensión como ésta prospere. Con todo, el artículo 69 inciso tercero de la Ley ${ }^{\circ}$ 19.039, Ley de Propiedad Industrial, contempla el derecho del prestador de servicios inventivos a una retribución adicional cuando éste, en cumplimiento de su encargo, obtenga una invención extraordinaria. Este derecho, según SierRa HeRrERO, también resulta aplicable al trabajador que, en cumplimiento de sus funciones laborales, obtenga una invención extraordinaria ${ }^{75}$. Cabe preguntarse si esta norma contempla una regla de carácter especial o trasunta el principio de equilibrio contractual; si fuese este último el caso, entonces habría un sustento normativo importante para construir una regla analógica que permita al trabajador de servicios creativos, que ha cedido anticipadamente sus derechos, pedir una retribución adicional.

Más allá del punto anterior, en conformidad al artículo 73 inciso primero de la LPI, ya sea que la cesión anticipada se pacte en el contrato de trabajo mismo o en un acto posterior, ésta "deberá efectuarse por instrumento público o por instrumento privado autorizado ante notario" e "inscribirse en el Registro dentro del plazo de 6 o días, contado desde la fecha de celebración del respectivo acto o contrato".

La posibilidad de pactar la cesión anticipada en el mismo contrato de trabajo no debiese generar mayores dudas, sobre todo si se considera que tal cesión tiende a facilitar la satisfacción del interés originario y legítimo que el empleador alberga en la ejecución del contrato de trabajo, esto es, explotar económicamente, en el marco de su actividad habitual, la obra que el trabajador cree como consecuencia del cumplimiento de sus funciones laborales. En palabras de VALDÉs A LONSO, "no existe obstáculo alguno para que el pacto de transmisión de derechos de propiedad intelectual forme parte del contrato de trabajo. Yello, fundamentalmente, porque el contenido de dicho pacto se encuentra directamente relacionado con el fin que las partes se proponen obtener de la consecución del contrato de trabajo"76.

74 Entre nosotros, una interesante teorización del principio de equilibrio contractual puede verse en LÓPEZ (2015).

75 Sobre este tema y los distintos criterios para determinar cuándo se genera esta retribución, véase SIERRA (2011) pp. 175-177.

76 VALDÉS (2OO1) p. 152. 
En Colombia, cuya normativa en esta materia es bastante similar a la nuestra, URIBE CORzo señala que "con el fin de radicar los derechos sobre la obra en cabeza del empleador se requiere que, al celebrar el contrato de trabajo, se determine claramente la obra a realizar y se acuerde la transferencia de los derechos por parte del trabajador. El contrato se debe formalizar según el artículo 183 de la ley autoral"77. El mencionado artículo 183 de la ley colombiana, al igual que el artículo 73 de la LPI, exige que la transferencia total o parcial de los derechos patrimoniales de autor conste en escritura pública o documento privado reconocido ante notario y sea registrado en la oficina de registros de derechos de autor.

Con todo, a diferencia de la LPI, la ley colombiana no establece un plazo para la inscripción en el registro. Evidentemente, el plazo de 60 días establecido por el artículo 73 de la LPı resulta problemático para aquellos casos en que el pacto de cesión anticipada esté contenido en el contrato de trabajo y el trabajador no cree la obra dentro del plazo de 6o días contados desde su celebración, pues el artículo 75 de la misma ley, al exigir la entrega de un ejemplar al momento en que se requiere la inscripción, presupone que la obra ya ha sido creada.

Aun cuando se estime que la inscripción constituye una mera formalidad por vía de publicidad ${ }^{78}$ y que, por ende, su falta no impide que el Derecho de autor sea transferido, tal circunstancia no será indiferente al empleador. Después de todo, el artículo 8 inciso primero de la LPI establece que se presume autor de la obra a quien aparezca como tal al divulgarse aquella o aquel a quien, según la respectiva inscripción, pertenezca el ejemplar registrado. Ante este escenario, el empleador probablemente aspirará a que exista una inscripción en su favor, pues de esa manera podrá servirse de la presunción de titularidad, viendo reforzada la protección a su derecho.

Atendida la dificultad descrita en el párrafo anterior, si al momento de la celebración del contrato de trabajo puede preverse por el empleador que la obra no será creada dentro de los 60 días siguientes, podría resultar más conveniente incorporar una promesa de cesión y una autorización anticipada para utilizar la obra mientras no se efectúe la cesión. Si así se hiciese, la autorización anticipada debiese cumplir con las exigencias con-

77 URIBE (2007) p. 59.

78 SCHUSter (2009) p. 374. 
templadas en los artículos 19 y 20 de la LPI, teniendo presente, en todo caso, que la remuneración a que se refiere el inciso segundo del artículo 20 se encuentra en estos casos contenida en la remuneración pactada como contrapartida de la prestación de servicios personales bajo vínculo de subordinación y dependencia. Una vez creada la obra, además de estar autorizado el empleador para utilizarla en los modos y bajo las limitaciones pactadas, se hará exigible la obligación de celebrar el pacto que contenga la cesión del Derecho de autor, que deberá otorgarse por instrumento público o instrumento privado autorizado ante notario y ser inscrito en el Registro dentro del plazo de 60 días.

Así las cosas, cabe precisar si el pacto que contiene la cesión del Derecho de autor constituye un contrato autónomo o forma parte del contrato de trabajo mismo.

En cuanto a la cesión anticipada pactada en el contrato de trabajo, estimamos que no constituye un contrato autónomo, sino que forma parte de la estructura misma del contrato de trabajo. En los términos del artículo 1444 del cc, la cesión anticipada constituye una cosa accidental, esto es, una cosa que no pertenece ni esencial ni naturalmente al contrato de trabajo celebrado con un trabajador que asume una o más funciones creativas, agregándose por medio de una cláusula especial ${ }^{79}$. Por lo demás, el mismo artículo $10 \mathrm{n}^{\circ} 7$ del Ст permite que el contrato de trabajo contenga pactos voluntarios. En virtud de este pacto, el contrato de trabajo sirve como título translaticio para la tradición del Derecho de autor, facilitando con ello al empleador el aprovechamiento económico de la obra en el marco de su actividad habitual. Este planteamiento es consistente con la circunstancia de que, bajo las reglas pertinentes de nuestro ordenamiento jurídico, la cesión de derechos no constituye por sí misma un contrato, sino únicamente la forma de hacer la tradición de un derecho. Así fluye del artículo 1901 del cc para el caso de los derechos personales y de los artículos 7 y 73 de la LPı para el caso de los derechos de autor; en ambos casos se distingue entre la cesión o transferencia propiamente tal y el título que sirve a ésta. De esta manera, el título que sirve a la cesión anticipada es justamente el contrato de trabajo.

79 Conviene recordar que, en aquellos casos en que los servicios personales prestados bajo vínculo de subordinación y dependencia no consistan en servicios creativos, el principio de ajenidad recobra todo su vigor, atribuyéndose directa y originariamente al empleador los frutos de la actividad laboral. 
En el caso de la cesión pactada en un acto posterior al contrato de trabajo, la cuestión se torna más compleja; si aquel acto, que sirve de título a la cesión propiamente tal, no ha sido precedido de una promesa de cesión pactada en el contrato de trabajo, estimamos que el acto deberá ser calificado como una compraventa o una donación según se estipule o no el pago de un precio - debiendo cumplir, en cada caso, con los requisitos contemplados en el cc para la celebración del contrato que se trate y los propios de la LPI-. En cambio, si la cesión se celebra como consecuencia de una promesa contenida en el contrato de trabajo, tal cesión no constituirá sino el cumplimiento de una obligación contraída por el trabajador-subsumible en su obligación de prestar servicios personales bajo vínculo de subordinación y dependencia-, cuya causa objetiva residirá en la obligación recíproca del empleador de pagar una remuneración.

Antes de terminar este capítulo conviene hacer una última aclaración. Para efectos de entender adecuadamente la cesión, no se debe perder de vista que, en conformidad al artículo 1 de la LPI, el Derecho de autor nace en la persona del autor; a mayor abundamiento, sólo cuando se ha creado una obra, y en la medida que ésta cumpla con los requisitos legales, es posible predicar la existencia del Derecho de autor, derecho que necesariamente habrá nacido en la persona y en el patrimonio del autor. Así las cosas, desde un punto de vista lógico y admitiendo ya la validez de la cesión anticipada, preciso es reconocer que las prerrogativas patrimoniales que integran el Derecho de autor alcanzan a radicarse un instante siquiera en el patrimonio del autor, transcurrido el cual se entienden transferidas al cesionario. Por lo demás, el reconocimiento de que el Derecho de autor se ha radicado al menos un instante en la persona y en el patrimonio del autor es una consecuencia necesaria de la atribución de la titularidad originaria al autor.

Ahora bien, aun cuando entre nosotros sea plausible entender que la transferencia, esto es la tradición, se produce un instante después de que el derecho se radique en la persona y patrimonio del autor, la posibilidad de que el empleador explote económicamente la obra presupone que ésta le haya sido materialmente entregada ${ }^{80}$. Por ende, en atención a la

80 Probablemente ésta sea la razón por la cual el artículo 51.2 de la ley de propiedad intelectual española, que presume legalmente la cesión del Derecho de autor a favor del empleador, establece que ésta se entiende perfeccionada "en el momento de la entrega de la obra". 
función integradora que desempeña la buena fe como principio general del Derecho ${ }^{81}$, estimamos que el trabajador tiene el deber de entregar materialmente la obra.

\section{ALCANCES DE LA CESIÓN ANTICIPADA}

Como se ha sugerido previamente, la cláusula de cesión anticipada contenida en un contrato de trabajo no puede ser redactada en términos genéricos o vagos, sino que debe referirse específicamente al Derecho de autor que adquiera el trabajador sobre las obras creadas en virtud del cumplimiento de funciones laborales clara y precisamente determinadas. Además, a fin de reforzar la protección de los intereses del autor y en base al concepto de empresa contemplado en el artículo 3 inciso tercero del CT, estimamos que el alcance de la cesión está limitado por los fines económicos, sociales, culturales o benéficos que la empresa persiga. Este último límite contribuye a determinar si la cesión involucra a todas y cada una de las prerrogativas patrimoniales que integran el Derecho de autor o solamente algunas de las que contempla el artículo 19 de la LPI.

Ahora bien, una vez creada la obra y determinados los límites de la cesión, cabe señalar que el ejercicio por parte del empleador de las prerrogativas patrimoniales de las que pasa a ser titular podría afectar algunas de las prerrogativas morales contempladas en el artículo 14 de la LPI. En efecto, la atribución derivativa del Derecho de autor al empleador, si bien en principio no alcanzaría jamás a los derechos morales -en tanto se trata de derechos personalísimos e inalienables-, igualmente podría presuponer la renuncia al derecho al inédito y excepcionalmente la autorización para modificar la obra. A mayor abundamiento, si la cesión tiene por finalidad hacer posible la explotación económica de las obras por parte del empleador y para tal cometido se requiere divulgar la obra o excepcionalmente modificarla, se torna necesario colegir la autorización del trabajador-autor para el ejercicio de tales prerrogativas. En palabras de Rodríguez Hidalgo y Álvarez Cuesta, "el contra-argumento más obvio y lógico pondría de manifiesto que el empresario tan sólo obtendría utilidad patrimonial de los derechos de explotación y no de los morales; esto es, que

81 BoetsCh (2015) pp. 93-97. 
el objeto del contrato atiende simplemente a la cesión de los primeros. Pero esto tampoco es enteramente cierto debido al carácter medial de determinados derechos morales para la posible explotación de la obra"82.

En cuanto al derecho de integridad, tal como sugiere Schuster Vergara, habría que distinguir si los servicios personales que debe prestar el trabajador tienden a la creación de una obra individual o si, en cambio, "se trata de aportes creativos destinados a ser complementados con otros aportes, o que por su naturaleza requieren en el giro mismo de la empresa una habitual actualización o adecuación, sea por el empleador u otros dependien$t^{\prime \prime}{ }^{\prime 83}$. En el primer caso, el empleador no podría modificar la obra sin el consentimiento expreso y previo del autor. En el segundo caso, bajo el entendimiento de SCHUSTER Vergara, la autorización estaría implícita en la naturaleza de los servicios que el trabajador debe prestar al empleador ${ }^{84}$.

En nuestra opinión, la autorización no puede estar contenida en la mera determinación de la naturaleza de los servicios pues, a falta de cesión o autorización expresa y determinada, el empleador no puede aprovecharse en ningún sentido de la obra. En nuestro concepto, la autorización está contenida en la cesión, toda vez que la intención del cedente de transferir el Derecho de autor importa el reconocimiento e intención de que el empleador, una vez realizada la tradición, pueda explotar económicamente la obra, lo que supone, en caso de obras que por su naturaleza requieran adecuación constante o que formen parte de un proyecto creativo superior, la autorización para modificar la obra. Con todo, esta autorización se acota a las modificaciones que sean estrictamente necesarias para la realización del proyecto creativo superior, no pudiendo jamás, aclarado sea, rebasar las limitaciones temporales, territoriales y de cualquiera otra índole que hayan estado contempladas en la cesión.

Respecto al derecho moral a mantener la obra inédita, SCHUSTER VERGARA entiende que "siendo el objeto del contrato la realización de obras intelectuales, no hay duda que el autor ha manifestado en la celebración del contrato su voluntad de que ella sea publicada, y es posible concluir que no hay restricción alguna para que el empleador lleve a cabo dicha actividad, sin consulta

82 Rodríguez y Álvarez (2004) p. 36.

83 SChuster (2OO9) p. 372.

84 Ibíd., pp. 372 y 373. 
específica al autor ${ }^{\prime \prime 85}$. Nuevamente estamos en desacuerdo con el autor precitado, pues nos parece contrario a nuestro ordenamiento - particularmente a los artículos 7, 19 y 20 de la LPI- desprender una autorización tácita para la utilización de una obra del sólo hecho de la celebración del contrato de trabajo. En realidad, es la cesión del Derecho de autor, y particularmente la cesión de la prerrogativa patrimonial de publicar la obra, la que por sí entraña la renuncia del autor a su facultad de mantener la obra inédita.

En relación a la posibilidad -o imposibilidad- del empleador de terminar la obra inconclusa, esta vez compartimos plenamente la opinión de SCHUSTER Vergara, quien afirma que "la facultad de publicar del empleador se ve limitada por la determinación del autor de no encontrarse acabada su creación y por tanto no podría llevarse a cabo la publicación. La determinación de encontrarse terminada la obra sólo puede establecerla el autory es parte del ejercicio del Derecho constitucional a la libertad de creación"86. En efecto, si bien el Derecho de autor es un derecho contingente -pues supone la creación de una obra que cumpla determinados requisitos legales-, la libertad de creación, en cambio, es efectivamente consustancial a las personas naturales, revistiendo en consecuencia la naturaleza de derecho de la personalidad. Por ende, la cesión anticipada del Derecho de autor que el trabajador adquiera sobre una obra se refiere siempre a una obra concluida. En este sentido, dado que la creación es un proceso -en tanto implica la acción y efecto de crear-, ninguna cláusula o pacto de cesión podrá referirse a obras inconclusas pues, si así fuese, tendrá un contenido contrario al Derecho Público chileno, adoleciendo de objeto ilícito -artículo 1462 del cc-y sancionándose con nulidad absoluta; tal cláusula o pacto sería contrario al artículo $19 \mathrm{n}^{\circ} 25$, que, en tanto asegura a todas las personas la libertad de creación, resguarda la integridad del proceso creativo. Desde otra perspectiva, la constitucionalización del Derecho del Trabajo no se agota en el respeto a los derechos fundamentales como límite al ejercicio de las facultades que la ley laboral reconoce al empleador -artículos 5 y 485 del CT-; el respeto a los derechos fundamentales se alza también como un límite infranqueable para el empleador al momento de predisponer aquellos aspectos del contrato de tra- 
bajo que no se encuentran imperativamente regulados en la ley laboral -artículo 1546 del cc.

Finalmente, no se visualiza ninguna razón por la cual pueda justificarse que el empleador se excuse de respetar la prerrogativa que el artículo 14 $\mathrm{n}^{\circ} 5$ de la LPI concede al autor, esto es, "exigir que se respete su voluntad de mantener la obra anónima o seudónima mientras ésta no pertenezca al patrimonio cultural común". La autorización para el ejercicio de las prerrogativas de divulgación y excepcional modificación de la obra no es tácita, pues no deriva de una mera conducta de la cual se desprenda inequívocamente una manifestación de voluntad en un sentido determinado. En realidad, la autorización está contenida en el alcance natural de la cesión, pues, en atención a la actividad económica desarrollada por el empleador y la naturaleza de los servicios prestados por el trabajador, podría resultar lógicamente imposible concebir la explotación económica de la obra sin la posibilidad de divulgarla y excepcionalmente de modificarla.

Finalmente, en cuanto al denominado derecho de participación, en Derecho comparado, en función del principio de ajenidad, se ha planteado por cierta doctrina que los autores de obras creadas en cumplimiento de funciones laborales no serían titulares de derecho de participación alguno, toda vez que todas las prerrogativas patrimoniales sobre tales obras se radicarían originariamente en el patrimonio de los empleado$\mathrm{res}^{87}$. En Chile ciertamente no podría prevalecer un entendimiento como éste, toda vez que, en conformidad al artículo 7 de la LPI y sin perjuicio de los casos excepcionales, los titulares originarios de los derechos de autor sobre las obras creadas en cumplimiento de sus funciones laborales son los trabajadores. De esta manera, cuando la naturaleza de la obra creada por un trabajador dependiente permita predicar la existencia del derecho de participación, el empleador deberá respetar irrestrictamente ese derecho, manteniéndose siempre radicado en el patrimonio del primero.

87 Rodríguez (1997) p. 798. 


\section{CONCLUSIONES}

1. La LPI contiene normas que, aisladamente consideradas, permiten sustentar tanto una concepción dualista como una monista del Derecho de autor. No obstante, en base a los artículos 1 inciso segundo de la LPI y 19 $\mathrm{n}^{\circ} 25$ inciso segundo de la CPR, es posible concluir que nuestro ordenamiento jurídico recoge una concepción monista. Los derechos patrimonial y moral a que se refieren las normas precitadas, en realidad, son facultades que integran el contenido de un derecho subjetivo único.

2. En nuestro ordenamiento jurídico, en atención a las dificultades para categorizar al Derecho de autor, éste puede concebirse como "un derecho subjetivo absoluto sobre un bien inmaterial, temporalmente limitado, integrado por facultades de orden moral y patrimonial. En suma, es un derecho subjetivo absoluto de carácter sui géneris en función de su objeto" ${ }^{\prime 8}$.

3. La determinación de la naturaleza jurídica del Derecho de autor, unida a la transferibilidad que en general le reconocen los artículos 7 y 73 de la LPI, permite sostener, consistentemente, la posibilidad de ceder tal derecho en favor de un tercero. Ello no obsta, con todo, a que la propia LPI, en sus artículos 16 y 36, establezca la intransferibilidad de las prerrogativas morales y del derecho de participación, que, siendo personalísimos, pertenecerán siempre al autor.

4. La cuestión de la titularidad del Derecho de autor sobre una obra creada por un trabajador en cumplimiento de sus funciones entraña una colisión entre dos principios que informan a ramas distintas del ordenamiento jurídico. Por una parte, el principio de ajenidad -que encuentra su soporte normativo más concreto en la letra a del artículo 3 del CT- puja por la atribución del derecho al empleador; por el otro, el entendimiento de la creación intelectual como un reflejo de la personalidad del autor, puja por la atribución del derecho al trabajador. Sin perjuicio de que las soluciones no son uniformes en Derecho comparado, en Chile, salvo casos excepcionales, la titularidad es atribuida al autor. Así se desprende del artículo 7 de la LPI, conclusión que se refuerza atendido el tenor del artículo $19 \mathrm{n}^{\circ} 25$ de la CPR.

88 Espín (1994) pp. 27 y 28. 
5. Sin perjuicio de que la titularidad del derecho sea atribuida al autor, es posible pactar en el contrato de trabajo o un acto posterior la cesión del derecho en favor del empleador. En caso que la cesión esté pactada en el mismo contrato de trabajo, ésta tiene el carácter de anticipada y se refiere a los derechos que el trabajador adquiera sobre las obras que cree en cumplimiento de sus funciones laborales. Esta cesión tiene un objeto que cumple con los requisitos del artículo 1461 del cc, a saber, una cosa real, comerciable y determinada genéricamente. Es real pues efectivamente se espera que el derecho exista; es comerciable en tanto el mismo artículo 7 de la LPI admite la posibilidad de que el derecho se radique en el patrimonio de diversas personas, sea originaria o derivativamente; y es determinada genéricamente toda vez que el derecho que se cede anticipadamente recae sobre una obra que se creará en virtud del cumplimiento de funciones laborales claramente determinadas.

6. La cesión será lícita en la medida que se refiera únicamente a las prerrogativas patrimoniales. Las prerrogativas morales y el derecho de participación, en cambio, no se transferirán jamás, siendo nula la cesión a este respecto, tal como puede desprenderse de los artículos 16 y 36 de la LPI y 1466 del cc.

7. Aplicando por analogía el artículo 20 inciso segundo de la LPI, la cesión debe ser específica. Con todo, la exigencia de especificidad se agota en la necesidad de precisar las prerrogativas patrimoniales que se ceden y la posibilidad de establecer un límite temporal, un límite territorial y determinadas condiciones y límites para la explotación de una obra. No es necesario que exista una remuneración adicional, pues la cesión está suficientemente retribuida en la misma remuneración que se pacta en el contrato de trabajo como contrapartida de la prestación de servicios personales bajo vínculo de subordinación y dependencia. Con todo, si los beneficios derivados de la explotación económica de la obra van más allá de los márgenes razonables que el empleador ha previsto o podido prever, queda abierta la cuestión de si el trabajador puede solicitar la revisión de la remuneración.

En este escenario, la construcción de una regla analógica al artículo 69 inciso tercero de la Ley $n^{\circ} 19.039$ y una adecuada y mínima ponderación del principio de equilibrio contractual constituyen sustentos normativos que permiten avalar una tesis positiva. 
8. Ya sea que la cesión se pacte de manera anticipada en el mismo contrato individual de trabajo o en un momento posterior a la creación de la obra, ésta deberá observar las formalidades que establece el artículo 73 inciso primero de la LPI, esto es, "deberá efectuarse por instrumento público o por instrumento privado autorizado ante notario" e "inscribirse en el Registro dentro del plazo de 6 o días, contado desde la fecha de celebración del respectivo acto o contrato".

9. El plazo de 60 días establecido por el artículo 73 de la LPI resulta problemático para aquellos casos en que el pacto de cesión anticipada esté contenido en el contrato de trabajo y el trabajador no cree la obra dentro del plazo de 6 o días contado desde su celebración. En estos casos podría resultar más útil al empleador incorporar al contrato de trabajo una promesa de cesión y una autorización anticipada para utilizar la obra mientras no se efectúe la cesión. Tal autorización también debiese cumplir con las exigencias contempladas en los artículos 19 y 20 de la LPI.

10. La cesión no constituye por sí misma un contrato, sino simplemente la tradición del Derecho de autor. De esta manera, si la cesión está pactada en el contrato de trabajo, este último será el título que la justifica. $\mathrm{Si}$, en cambio, la cesión está pactada en un acto posterior, habrá que distinguir si ha sido o no precedida de una promesa. En caso que exista promesa previa, la cesión no constituye sino el cumplimiento de una obligación contraída por el trabajador en virtud del contrato de trabajo, cuya causa objetiva reside en la obligación del empleador de pagar una remuneración. Si no existe promesa previa, la cesión tiene por título una compraventa o una donación según se estipule o no el pago de un precio, debiéndose cumplir, en cada caso, con los requisitos que para cada uno de esos contratos exige el cc.

11. Para que opere la cesión y, por tanto, el empleador adquiera derivativamente la titularidad del Derecho de autor, forzoso es concluir que este derecho se ha radicado al menos un instante en la persona y patrimonio del autor. Así se deriva de los artículos 1 y 7 de la LPI. Con todo, aun cuando entre nosotros sea plausible entender que la transferencia, esto es la tradición, se produce un instante después de que el derecho se radique en la persona y patrimonio del autor, la posibilidad de que el empleador explote económicamente la obra presupone que ésta le haya sido materialmente entregada. En atención a la función integradora que 
cumple el principio general de la buena fe, el trabajador debe entregar materialmente la obra al empleador.

12. La atribución derivativa del Derecho de autor al empleador, si bien en principio no alcanzaría jamás a los derechos morales -en tanto se trata de derechos personalísimos e inalienables-, igualmente podría presuponer la renuncia al derecho al inédito y excepcionalmente la autorización para modificar la obra. En estos casos, la autorización no derivaría de la mera celebración del contrato individual de trabajo, sino que estaría contenida en el alcance natural de la cesión, no pudiendo aquélla rebasar las limitaciones temporales, territoriales y de cualquiera otra índole que ésta haya contemplado. Aun cuando se atribuya derivativamente el Derecho de autor al empleador, la prerrogativa de participación, si acaso es posible predicar su existencia en conformidad a los artículos 36 de la LPI y 14 ter del Convenio de Berna, se mantendrá siempre en el patrimonio del trabajador.

\section{BIBLIOGRAFÍA CITADA}

Alarcón, Manuel (1986): "La ajenidad en el mercado: un criterio definitorio del contrato de trabajo", Revista Española de Derecho del Trabajo, $\mathrm{n}^{\circ} 28$, pp. 495-544.

Alessandri, Arturo, Somarriva, Manuel y Vodanovic, Antonio (2005): Tratado de los derechos reales. Bienes (Santiago, Editorial Jurídica).

Alonso, Manuel y CaSAS, María (2006): Derecho del Trabajo (24 Edición, Madrid, Civitas).

BARCIA, RODRIGo (2007): Lecciones de Derecho Civil Chileno. Del acto jurídico. Tomo I, (Santiago, Editorial Jurídica de Chile).

BenAVENTE, Hesbert (2005): "La teoría trialista del know how y sus repercusiones en la propiedad intelectual", en IGLESIAS, César (coord.), Propiedad Intelectual, Derechos Fundamentales y Propiedad Industrial (Madrid, Editorial Reus S.A.), pp. 13-48. 
Bertrand, André (1991): Le droit d'auteur et les droits voisins (2 ${ }^{\text {a }}$ Edición, París, Dalloz).

Boetsh, Cristián (2015): La buena fe contractual (Santiago, Ediciones Universidad Católica de Chile).

Colombet, Claude (1999): Propriété littéraire et artistique et droits voisins (París, Dalloz).

De Román, Raquel (2005): “Naturaleza jurídica del Derecho de autor", en IGLESIAS, César (coord.), Propiedad Intelectual, Derechos Fundamentales y Propiedad Industrial (Madrid, Editorial Reus S.A.), pp. 13-48.

Domínguez, Ramón (2012): Teoría general del negocio jurídico (2 ${ }^{\text {a }}$ Edición, Santiago, Editorial Jurídica de Chile).

Domínguez, Carmen (2009): "Los derechos de la personalidad y el principio de reparación integral del daño", en VAras, Juan, Turner, Susan, Corral, Hernán, Rodríguez, María, Guzmán, Alejandro y Pizarro, Carlos (coords.), Estudios de Derecho Civil, Jornadas Nacionales de Derecho Civil 2005-2009, Tomo IV (Santiago, Legal Publishing), pp. 409-423.

DwOrkIN, Ronald (1984): Los derechos en serio (traducción de Marta Guastavino) (Barcelona, Editorial Ariel).

Espín, Isabel (1994): Contrato de Edición Literaria (un estudio del Derecho de autor aplicado al campo de la contratación) (Granada, Comares).

Fueyo, Fernando (1990): Instituciones de Derecho Civil moderno (Santiago, Editorial Jurídica de Chile).

Gautier, Pierre-Yves (1999): Propriété littéraire et artistique (París, PUF).

GuZmÁN, Alejandro (2006): Las cosas incorporales en la doctrina y en el Derecho positivo ( ${ }^{\text {a }}$ Edición, Santiago, Editorial Jurídica de Chile).

Hernando, Aurora (2000): El contrato de franquicia de empresa (Madrid, Civitas). 
IRURETA, Pedro (2014): “La noción jurídica de empleador ante el derecho del trabajo", Revista de Derecho de la Pontificia Universidad Católica de Valparaíso, $\mathrm{n}^{\circ}$ 42, pp. 251-282.

LAMAS, Mario (2009): "Los derechos de propiedad intelectual en las relaciones laborales. El caso uruguayo", en VeLASCO, Rodrigo y MORALES, Marcos (coords.), Estudios de Derecho y Propiedad Intelectual, Colección de trabajos en homenaje a Arturo Alessandri Besa (Santiago, Editorial Jurídica), pp. 159-183.

LIPSZYC, Delia (2006): Derecho de autor y derechos conexos (Argentina, CERLALC).

LóPEZ, Patricia (2015): “El principio de equilibrio contractual en el Código Civil chileno y su particular importancia como fundamento de algunas instituciones del moderno derecho de las obligaciones en la dogmática nacional", Revista Chilena de Derecho Privado, n² 25, pp. 115-181.

LYON, Alberto (2006): "La voluntad virtual derivada de la 'naturaleza' del contrato determinada por su causa", en CORRAL, Hernán y RodríGuEZ, María (coords.), Estudios de Derecho Civil II, Jornadas Nacionales de Derecho Civil 2006 (Santiago, LexisNexis), pp. 753-792.

RodríGuez, José y Álvarez, Henar (2004): La siempre conflictiva relación laboral del trabajador intelectual y un apunte específico para el creador de software (León, Universidad de León).

Rodríguez, José (1997): “Comentario al artículo 51", en BerCovitz, Rodrigo (coord.), Comentarios a la Leyde propiedad intelectual ( $2^{\mathrm{a}}$ Edición, Madrid, Tecnos) pp. 760-810.

Roselló, Rafael (2011): Derechos de la personalidad y derechos morales de los autores (Madrid, Editorial Reus S.A.).

SCHUSTER, Santiago (2009): "Derechos de autor en las relaciones laborales y su vínculo con el Tratado de Libre Comercio entre Chile y Estados Unidos", en Velasco, Rodrigo y Morales, Marcos (coords.), Estudios de Derecho y Propiedad Intelectual, colección de trabajos en homenaje a Arturo Alessandri Besa (Santiago, Editorial Jurídica), pp. 369-384. 
SIERRA, Alfredo (2011): "Trabajadores inventores: titularidad de sus creaciones y régimen retributivo", Revista de Derecho de la Universidad Católica del Norte, $\mathrm{n}^{\circ}$ 2, pp. 151-188.

SQUeLLA, Agustín (2008): Introducción al Derecho (Santiago, Editorial Jurídica de Chile).

URIBE, María (2007): "El Derecho de autor en las obras creadas por encargo y en el marco de una relación laboral", Revista de la Propiedad Inmaterial, $\mathrm{n}^{\circ}$ 10-11: pp. 45-70.

URQUIETA, Carlos (2012): "Propiedad y posesión sobre bienes inmateriales", en Elorriaga, Fabián (coord.), Estudios de Derecho Civil VII: Jornadas Nacionales de Derecho Civil 2011 (Santiago, Legal Publishing), pp. 195-214.

_-(2013): "Autoría y titularidad de las creaciones del trabajador", sin editar.

VALDÉs, Alberto (2001): Propiedad intelectual y relación de trabajo. La transmisión de los derechos de propiedad intelectual a través del contrato de trabajo. Artistas, programadores informáticos y producción audiovisual (Madrid, Editorial Civitas).

VIAL, Víctor (2003): Teoría general del acto jurídico (2 ${ }^{\mathrm{a}}$ Edición, Santiago, Editorial Jurídica de Chile).

WALKer, Elisa (2013): Manual de Propiedad Intelectual (Santiago, Legal Publishing Chile).

\section{NORMAS JURÍDICAS CITADAS}

Acuerdo de Marrakech, por el que se establece la Organización Mundial del Comercio, y los acuerdos anexos que se indican- ratificado por Chile y promulgado mediante Decreto Supremo n 16, de 1995, del Ministerio de Relaciones Exteriores.

Código Civil, del 14 de diciembre de 1855 . 
Código del Trabajo, del 24 de enero de 1994.

Constitución Política de la República, del 8 de agosto de 1980.

Convenio de Berna, ratificado y promulgado por Chile mediante Decreto Supremo n²66, de 1975, del Ministerio de Relaciones Exteriores.

Ley $\mathrm{n}^{\circ}$ 17.336, del 2 de octubre de 1970, sobre propiedad intelectual.

Ley $\mathrm{n}^{\circ}$ 19.039, del 11 de marzo de 2005, que establece la Ley de Propiedad Industrial.

Protocolo por el que se enmienda el Acuerdo sobre los Aspectos de los Derechos de Propiedad Intelectual Relacionados con el Comercio, establecido por Decreto $\mathrm{n}^{\circ}$ 97, del 4 de noviembre de 2017, del Ministerio de Relaciones Exteriores.

Tratado de la Organización Mundial de la Propiedad Intelectual (OMPI) sobre Derecho de Autor, ratificado por Chile y promulgado el 14 de marzo de 2001 mediante Decreto Supremo ${ }^{\circ}$ 270, de 2003, del Ministerio de Relaciones Exteriores.

Tratado de la Organización Mundial de la Propiedad Intelectual (OMPI) sobre Derecho de Autor, establecido por Decreto $n^{\circ} 270$, del 7 de marzo de 2003, del Ministerio de Relaciones Exteriores. 